\title{
Convergent functional genomic studies of omega-3 fatty acids in stress reactivity, bipolar disorder and alcoholism
}

\author{
H Le-Niculescu', NJ Case ${ }^{1}$, L Hulvershorn ${ }^{1}$, SD Patel ${ }^{1,4}$, D Bowker ${ }^{1}$, J Gupta ${ }^{1}$, R Bell ${ }^{1}$, HJ Edenberg ${ }^{2}$, MT Tsuang ${ }^{3}$, R Kuczenski ${ }^{3}$, \\ MA Geyer ${ }^{3}$, ZA Rodd ${ }^{1}$ and AB Niculescu, ${ }^{1,4}$
}

Omega-3 fatty acids have been proposed as an adjuvant treatment option in psychiatric disorders. Given their other health benefits and their relative lack of toxicity, teratogenicity and side effects, they may be particularly useful in children and in females of child-bearing age, especially during pregnancy and postpartum. A comprehensive mechanistic understanding of their effects is needed. Here we report translational studies demonstrating the phenotypic normalization and gene expression effects of dietary omega-3 fatty acids, specifically docosahexaenoic acid (DHA), in a stress-reactive knockout mouse model of bipolar disorder and co-morbid alcoholism, using a bioinformatic convergent functional genomics approach integrating animal model and human data to prioritize disease-relevant genes. Additionally, to validate at a behavioral level the novel observed effects on decreasing alcohol consumption, we also tested the effects of DHA in an independent animal model, alcohol-preferring (P) rats, a well-established animal model of alcoholism. Our studies uncover sex differences, brain region-specific effects and blood biomarkers that may underpin the effects of DHA. Of note, DHA modulates some of the same genes targeted by current psychotropic medications, as well as increases myelin-related gene expression. Myelin-related gene expression decrease is a common, if nonspecific, denominator of neuropsychiatric disorders. In conclusion, our work supports the potential utility of omega-3 fatty acids, specifically DHA, for a spectrum of psychiatric disorders such as stress disorders, bipolar disorder, alcoholism and beyond.

Translational Psychiatry (2011) 1, e4; doi:10.1038/tp.2011.1; published online 26 April 2011

\section{Introduction}

'First do no harm'

\section{-Hippocratic Oath}

There is a strong need for better treatments, with less side effects, for stress, mood and alcohol use disorders. Natural compounds may offer a source for such treatments, but have been in general insufficiently studied in preclinical models, and a molecular understanding is lacking. Omega-3 fatty acids (eicosapentaenoic acid and docosahexaenoic acid (DHA)) are essential fatty acids, with DHA being the final metabolic pathway compound. They have been speculated to have had an evolutionary role in the development of the brain in higher organisms, ${ }^{1}$ and their relative depletion compared with proinflammatory omega- 6 fatty acids in modern Western diets has been invoked as having a role in the pathophysiology of multiple diseases. ${ }^{2}$ Omega-3 fatty acids, particularly DHA, have been described to have mood- and psychosismodulating properties, in both preclinical models and some clinical trials. For example, deficits in omega-3 fatty acids have been linked to increased depression and aggression in animal models ${ }^{3,4}$ and humans. ${ }^{5,6}$ Of note, deficits in DHA have been reported in erythrocytes ${ }^{7}$ and in the post-mortem orbitofrontal cortex of patients with bipolar disorder, and were greater in those who had high vs those who had low alcohol abuse. ${ }^{8}$ Omega-3 fatty acids have been reported to be clinically useful in the treatment of both $\operatorname{mood}^{9-12}$ and psychotic disorders. ${ }^{13-15}$ To date, there is no clear understanding of how they work in terms of psychotropic effects, or indeed how well they actually work. Unlike most psychiatric drugs, these natural compounds have minimal side effects, and intriguing evidence for favorable health benefits. ${ }^{16-18}$ Particularly for children and female patients of child-bearing age, the potential developmental and teratogenic side effects of mood-stabilizing and antidepressant medications are a major issue. As such, if the action of omega-3 fatty acids in mood disorders and other related disorders could be substantiated by understanding their mechanistic effects and the identification of candidate molecular biomarkers for treatment response, they would become an important consideration as an addition to the therapeutic armamentarium of psychiatrists, pediatricians and primary care doctors.

We have previously identified the circadian clock gene $D$-box binding protein $(D B P)$ as a potential candidate gene for bipolar disorder, ${ }^{19}$ as well as for alcoholism ${ }^{20}$ and schizophrenia, ${ }^{21}$ using a convergent functional genomics

${ }^{1}$ Department of Psychiatry, Indiana University School of Medicine, Indianapolis, IN, USA; ${ }^{2}$ Department of Biochemistry and Molecular Biology, Indiana University School of Medicine, Indianapolis, IN, USA; ${ }^{3}$ Department of Psychiatry, UC San Diego, La Jolla, CA, USA and ${ }^{4}$ Indianapolis VA Medical Center, Indianapolis, IN, USA Correspondence: Professor AB Niculescu, Department of Psychiatry, Indiana University School of Medicine, 791 Union Drive, Indianapolis, IN 46202, USA. 
(CFG) approach. In follow-up work, we established mice with a homozygous deletion of DBP (DBP knockout (KO)) as a stress-reactive genetic animal model of bipolar disorder and co-morbid alcoholism. ${ }^{22}$ We reported that DBP KO mice have lower locomotor activity and blunted responses to stimulants and they gain less weight over time. In response to a chronic stress paradigm, the mice exhibit a diametric switch in these phenotypes. DBP KO mice are also activated by sleep deprivation, similar to bipolar patients, and that activation is prevented by treatment with the mood stabilizer drug valproate. Moreover, these mice show increased alcohol intake following exposure to stress. Microarray studies of brain and blood revealed a pattern of gene expression changes that may explain the observed phenotypes. CFG analysis of the gene expression changes identified a series of novel candidate genes and blood biomarkers for bipolar disorder, alcoholism and stress reactivity.

Based on the above, we decided to test omega-3 fatty acids, specifically $\mathrm{DHA}$, at a phenotypic, gene expression and blood biomarker level, in this animal model (DBP KO mice subjected to a chronic stress paradigm), using a case-case design $^{23}$ to increase signal detection and focus on the effects of DHA. We also studied the effects of DHA on modulating alcohol consumption in these mice and in an independent animal model, the alcohol-preferring $(P)$ rats, a well-established model of alcoholism. Of note, there is a high degree of co-morbidity of alcoholism with depression ${ }^{24,25}$ as well as with bipolar disorder. ${ }^{26}$ The work described has important translational implications for understanding and validating a new treatment approach, which follows the Hippocratic principle of 'first do no harm' and may favorably impact multiple co-morbid medical and psychiatric conditions.

\section{Materials and methods}

Mouse colony. The generation of transgenic mice carrying DBP-KO has been previously described in detail. ${ }^{22}$ DBP $(+/-)$ heterozygous (HET) mice were bred to obtain mixed littermate cohorts of DBP $(+/+)$ wild-type (WT), HET and DBP (-/-) KO mice. Mouse pups were weaned at 21 days and housed by gender in groups of two to four in a temperature- and light-controlled colony on reverse cycle (lights on at $2200 \mathrm{~h}$, lights off at $1000 \mathrm{~h}$ ), with food and water available ad libitum. DNA for genotyping was extracted by tail digestion with a Qiagen DNeasy Tissue kit, following the protocol for animal tissue (Qiagen, Valencia, CA, USA). The following three primers were used for genotyping by PCR: Dbp forward: 5' -TTCTTTGGGCTTGCTGTTTCCCTGCAGA-3' Dbp reverse: 5'-GCAAAGCTCCTTTCTTTGCGAGAAGTGC-3' (WT allele)

lacZ reverse: 5'-GTGCTGCAAGGCGATTAAGTTGGGTAAC-3' (KO allele)

WT or KO mice, 8-12 weeks old, were used for experiments.

Animal housing, diets and treatment. All mice were housed for at least 1 week before each experiment in a room set to an alternating light cycle with $12 \mathrm{~h}$ of darkness from 1000 to $2200 \mathrm{~h}$, and $12 \mathrm{~h}$ of light from 2200 to $1000 \mathrm{~h}$. At the start of the experiment, male and female DBP $(+/+)$ WT or DBP (-/-) KO mice were placed on one of the two diets:
(1) low DHA custom research diet (TD 00522, Harlan Teklad, Madison, WI, USA), a DHA-depleting low n-3 PUFA test diet adequate in all other nutrients (n-6/n-3 ratio of $85: 1$ with $6 \%$ fat as safflower oil); ${ }^{27}$ or (2) high DHA custom research diet (TD 07708 low-DHA diet supplemented with $0.69 \%$ algal DHA; Martek Bioscience, Columbia, MD, USA). ${ }^{27}$ The DBP mice were fed the low-DHA diet $(0 \% \mathrm{DHA})$ or high-DHA diet $(0.69 \% \mathrm{DHA})$ for 28 days. Mice and food and water were weighed twice a week. Water was refilled once a week.

Mice were subjected to a chronic stress paradigm consisting of isolation (single housing) for 28 days, with an acute stressor (behavioral challenge tests) on day 21. The behavioral challenge tests consisted of sequential administration of the forced swim test (FST), tail flick test and tail suspension test.

At 4 weeks (day 28), the mice were injected with saline to keep handling consistent with previous work $^{22}$ and their open field locomotor activity was assessed with SMART II video-tracking software (San Diego Instruments, San Diego, CA, USA). After video tracking, brain and blood were harvested as previously described ${ }^{22}$ for use in microarray studies.

\section{Behavioral challenge tests}

Forced Swim Test. FST experiments were performed on day 21 of treatment during the dark cycle. Mice were placed one at a time in a transparent plexiglas cylinder $(64 \mathrm{~cm}$ height $\times 38 \mathrm{~cm}$ diameter), with water depth of $30 \mathrm{~cm}$ and temperature of $23 \pm 2{ }^{\circ} \mathrm{C}$. Water was replaced after each mouse tested. Time spent immobile in a 10-min interval was scored live by two independent observers blinded to the genotype and treatment group of the animals.

Tail flick. Immediately following the FST, the mice were dried with paper towels and placed in the Plexiglas chamber of the Tail Flick Analgesia Meter System (San Diego Instruments). The mouse's tail was placed over a window located on the Tail Flick platform where a light beam shines to heat the tail at a reliable, reproducible rate for $20 \pm 1 \mathrm{~s}$. This test was performed as an acute stressor, and not as a way to measure the mouse's response to pain, as it is confounded by the preceding test.

Tail suspension. For the third part of the acute stress paradigm, the mouse was suspended by its tail, $\sim 30 \mathrm{~cm}$ above the ground for $5 \mathrm{~min}$. This test was performed as an acute stressor, and not as a way to measure the mouse's behavior, as it is confounded by the preceding tests.

Locomotion testing. A SMART II Video Tracker (VT) system (San Diego Instruments) under normal light was used to track the movement of mice. The mice were placed in the lower-right-hand corner of one of four adjacent, $41 \times 41 \times 34 \mathrm{~cm}^{3}$ enclosures. Mice were not allowed any physical contact with other mice during testing. Each enclosure had nine predefined areas, that is, center area, corner area and wall area. The movements of the mice were recorded for $30 \mathrm{~min}$. The enclosures were cleaned with water after each tracking. Measures of total distance traveled, center entry, center time, fast movement, resting time, 
average velocity ( $\mathrm{V}$ mean) and maximum velocity ( $\mathrm{V}$ max) were obtained.

Clustering analysis of locomotion pattern using GeneSpring. GeneSpring GX (Agilent Technologies, Palo Alto, CA, USA), the most widely used, commercially available, microarray gene expression analysis software, was adapted for the novel use of analyzing and visualizing phenotypic data. We have inputted the scores on phenotypic items numbers in lieu of the usual use of gene expression intensity numbers. All the subsequent analyses were carried out using the same tools as for gene expression data sets, as per the manufacturer's instructions (www.chem.agilent.com). Unsupervised two-way hierarchical clustering of normalized (Z-scored) behavioral data from locomotor testing was carried out using methodology previously described. ${ }^{22,28}$

Alcohol consumption experiments in mice. To create an alcohol free-choice drinking paradigm, male DBP $(+/+)$ WT or DBP $(-/-) \mathrm{KO}$ mice were placed in individual cages with both a bottle of $\sim 250 \mathrm{ml}$ cold tap water and a bottle of $\sim 250 \mathrm{ml} \mathrm{10 \%}$ ethanol, the customary concentration used in mouse studies of alcohol consumption, and either a low- or high-DHA diet for 28 days, with an acute stressor (behavior challenge tests described above) on day 21 . The amount of ethanol and water consumed was recorded twice a week, at which time the locations of the bottles were switched to prevent positional bias. The bottles were refilled with fresh solution once a week.

Alcohol consumption experiments in alcohol-preferring (P) rats. Experimentally naive, male $P$ rats, 4-6 months of age at the start of the experiment, were used as subjects. They were placed on three diets (1) low DHA custom research diet (TD 00522, Harlan Teklad); (2) high omega-3 custom research diet (TD 07708, 0.69\% DHA), similar to the DBP KO mice experiments; and (3) normal rat diet (7001, Harlan Teklad) for a duration of 28 days. Food and water were available ad libitum throughout the experiments. Rats were given continuous free-choice access in the home cage to $15 \% \mathrm{v} / \mathrm{v}$ ethanol and water, the customary concentration used in rat studies of alcohol consumption. Ethanol intake was measured daily throughout the experiment.

Behavioral statistical analysis. Behavioral data are expressed as the mean \pm s.e.m. Two-way analysis of variance was used to determine statistically significant differences for factors of gender, genotype and diet, using SPSS statistical software (SPSS, Chicago, IL, USA). We used a one-tailed, two-sample independent $t$-tests assuming unequal variance to determine significant differences between individual groups. Differences between groups were considered significant at a $P<0.05$ (Figure 1).

RNA extraction and microarray work. Following the locomotor behavioral testing, mice were sacrificed by cervical dislocation, then they were decapitated and blood was collected. Behavioral testing and tissue harvesting were done at the same time of day in all experiments. The brains of the mice were harvested, stereotactically sliced, and hand microdissected using Paxinos mouse anatomical atlas coordinates, to isolate anatomical regions of interestprefrontal cortex (PFC), amygdala (AMY) and hippocampus (HIP). ${ }^{21,29}$ Tissues were flash frozen in liquid nitrogen and stored at $-80^{\circ} \mathrm{C}$ pending RNA extraction. Approximately 0.5-1 $\mathrm{ml}$ of blood per mouse was collected into a PAXgene blood RNA collection tubes (BD Diagnostics, Franklin Lakes, NJ, USA). The PAXgene blood vials were stored in $-4{ }^{\circ} \mathrm{C}$ overnight, and then at $-80^{\circ} \mathrm{C}$ until future processing for RNA extraction.

Standard techniques were used to obtain total RNA (22-gauge syringe homogenization in RLT buffer) and to purify the RNA (RNeasy mini kit, Qiagen) from microdissected mouse brain regions. For the whole mouse blood RNA extraction, PAXgene blood RNA extraction kit (PreAnalytiX, a QIAGEN/BD company, BD Diagnostics) was used, followed by GLOBINclear-Mouse/Rat (Ambion/Applied Biosystems, Austin, TX, USA) to remove the globin mRNA. All the methods and procedures were carried out as per the manufacturer's instructions. The quality of the total RNA was confirmed using an Agilent 2100 Bioanalyzer (Agilent Technologies). The quantity and quality of total RNA was also independently assessed by $260 \mathrm{~nm}$ ultraviolet absorption and by $260 / 280$ ratios, respectively (Nanodrop spectrophotometer, Thermo Scientific, Wilmington, DE, USA). Starting material of total RNA labeling reactions was kept consistent within each independent microarray experiment.

Equal amounts of total RNA extracted from the brain tissue samples or blood from three mice per group was pooled for each experimental condition and used for labeling and hybridization to Mouse Genome 4302.0 arrays (Affymetrix, Santa Clara, CA, USA). The GeneChip Mouse Genome 4302.0 Array contains over 45000 probe sets that analyze the expression level of over 39000 transcripts and variants from over 34000 well-characterized mouse genes. Standard Affymetrix protocols were used to reverse transcribe the messenger RNA and generate biotinlylate cRNA (http:// www.affymetrix.com/support/downloads/manuals/expression_ s2_manual.pdf). The amount of cRNA used to prepare the hybridization cocktail was kept constant within each experiment. Samples were hybridized at $45^{\circ} \mathrm{C}$ for $17 \mathrm{~h}$ under constant rotation. Arrays were washed and stained using the Affymetrix Fluidics Station 400 and scanned using the Affymetrix Model 3000 Scanner controlled by GCOS software. All sample labeling, hybridization, staining and scanning procedures were carried out as per the manufacturer's recommendations.

Quality control. All arrays were scaled to a target intensity of 1000 using Affymetrix MASv 5.0 array analysis software. Quality control measures including $3^{\prime} / 5^{\prime}$ ratios for glyceraldehyde 3-phosphate dehydrogenase and $\beta$-actin, scaling factors, background and $Q$ values were used.

Microarray data analysis. Data analysis was performed using Affymetrix Microarray Suite 5.0 software (MAS v5.0). Default settings were used to define transcripts as present $(\mathrm{P})$, marginal $(\mathrm{M})$ or absent $(\mathrm{A})$. A comparison analysis was performed for DBP KO mice on high-DHA diet, using DBP KO mice on low-DHA diet as the baseline. 'Signal', 
'Detection', 'Signal Log Ratio', 'Change' and 'Change $P$-value' were obtained from this analysis. An empirical $P$-value threshold for change of $P<0.0025$ was used. Only transcripts that were called Present and that were reproducibly changed in the same direction in two independent experiments were analyzed further.

Gene identification. The identities of transcripts was established using NetAFFX (Affymetrix), and confirmed by cross-checking the target mRNA sequences that had been used for probe design in the Affymetrix Mouse Genome 430 2.0 arrays GeneChip with the GenBank database. Probe sets that did not have a known gene are labeled 'EST' and their accession numbers kept as identifiers.

\section{Convergent Functional Genomics analyses}

Databases. We have established in our laboratory (Laboratory of Neurophenomics, IU School of Medicine) manually curated databases of all the human gene expression (postmortem brain, blood), human genetic (association, linkage) and animal model gene expression studies published to date on psychiatric disorders. These constantly updated large databases have been used in our CFG cross-validation (Figure 2).

Human genetic evidence (linkage, association). To designate convergence for a particular gene, the gene had to map within $10 \mathrm{cM}$ (see ref. 19 for detailed discussion) of a microsatellite marker for which at least one published study showed evidence of genetic linkage or a positive association study for the gene itself was reported in the literature (for bipolar disorder, depression, alcoholism, stress and anxiety). The University of Southampton's sequence-based integrated map of the human genome (The Genetic Epidemiological Group, Human Genetics Division, University of Southampton: http://cedar.genetics.soton.ac.uk/public_html/) was used to obtain $\mathrm{cM}$ locations for both genes and markers. The sex-averaged $\mathrm{cM}$ value was calculated and used to determine convergence to a particular marker. For markers that were not present in the Southampton database,

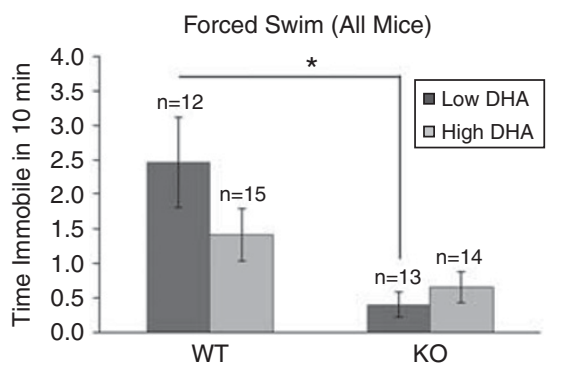

Genotype $\mathrm{x}$ Diet ANOVA $\mathrm{p}$-value $=0.102$

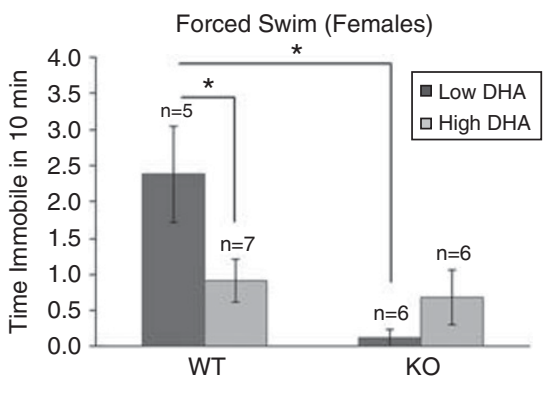

Genotype $x$ Diet ANOVA p-value $=0.015$

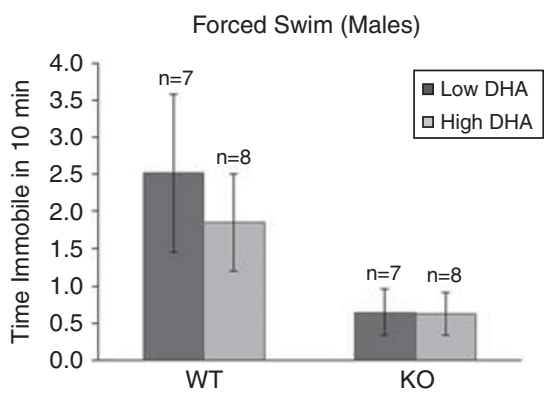

Genotype $\mathrm{x}$ Diet ANOVA p-value $=0.618$

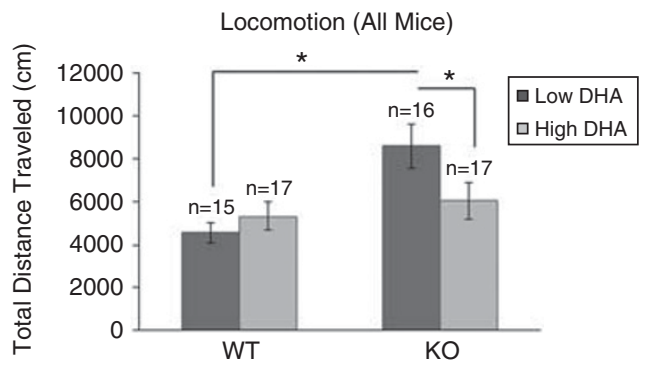

Genotype $\mathrm{x}$ Diet ANOVA p-value $=0.037$

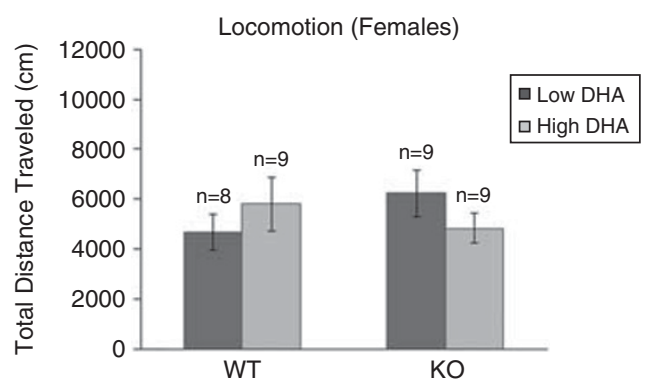

Genotype $x$ Diet ANOVA p-value $=0.157$

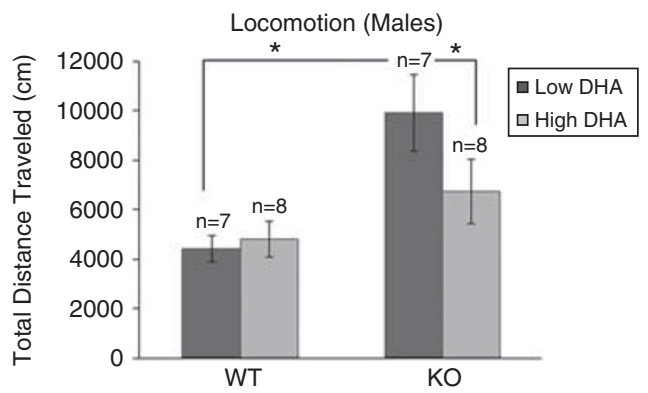

Genotype $x$ Diet ANOVA p-value $=0.053$

Figure 1 Effects of docosahexaenoic acid (DHA) on stressed mice behavior: DBP $(+/+)$ wild-type (WT) and DBP $(-/-)$ knockout (KO) mice on a diet either high or low in DHA were subjected to a chronic stress paradigm consisting of isolation (single housing) for 28 days, with an acute stressor (behavioral challenge tests, including forced swim test) at day 21.On day 28, video-tracking software was used to measure locomotion (total distance traveled, in centimeters) during a 30-min period in open field. Two-factor analysis of variance (ANOVA) was done for genotype and diet. Additionally, one-tail $t$-tests with ${ }^{*} P<0.05$ are depicted. 
the Marshfield database (Center for Medical Genetics, Marshfield, WI, USA: http://research.marshfieldclinic.org/ genetics) was used with the NCBI (National Center for Biotechnology Information) Map Viewer website to evaluate linkage convergence.

Human gene expression evidence (post-mortem brain, blood). Information about our candidate genes was obtained using GeneCards, the Online Mendelian Inheritance of Man database (http://ncbi.nlm.nih.gov/entrez/ query.fcgi? $\mathrm{db}=\mathrm{OMIM}$ ), as well as database searches using PubMed (http://ncbi.nlm.nih.gov/PubMed) and various combinations of keywords (gene name, bipolar, depression, alcoholism, stress, anxiety, brain, blood, lymphocytes). In addition to our own blood biomarker data for mood disorders, ${ }^{30}$ we also cross-matched with data for human blood biomarkers for hallucinations and delusions, ${ }^{31}$ as such symptoms occur in dissociative states related to stress and anxiety.

Mouse genetic evidence (quantitative trait loci (QTLs), transgenic). To search for mouse genetic evidence-QTLs or transgenic-for our candidate genes, we utilized the MGI_3.54-Mouse Genome Informatics (Jackson Laboratory, Bar Harbor, ME, USA) and used the search menu for mouse phenotypes and mouse models of human disease/abnormal behaviors, using the following subcategories: abnormal emotion/affect behavior and abnormal sleep pattern/ circadian rhythm, addiction and drug abuse. To designate convergence for a particular gene, the gene had to map within $10 \mathrm{cM}$ of a QTL marker for the abnormal behavior, or a transgenic mouse of the gene itself displayed that behavior.

Animal model gene expression evidence (brain, blood). Manually curated databases, developed in our lab, of published gene expression studies in animal models of bipolar disorder, depression, alcoholism, stress and anxiety were used for cross-matching with our list of genes changed in expression by DHA in the DBP KO mice (data from studies published by our own group received 1 point, whereas studies published by other groups received 0.5 points).

Convergent Functional Genomics (CFG) scoring. Only genes reproducibly changed in expression in the same mouse tissue (PFC, AMY, HIP, blood), in the same direction, in two independent experiments, were analyzed further. The six external cross-validating lines of evidence (three animal model, three human) were: animal model genetic data, animal model brain gene expression data, animal model blood gene expression data, human genetic data, human brain gene expression data and human blood gene expression data (see Figure 2). These lines of evidence received a maximum of 1 point each (for animal model genetic data, 0.5 points if it was QTL, 1 point if it was transgenic; for human genetic data, 0.5 points if it was linkage, 1 point if it was association). Thus, the maximum possible CFG score for each gene was 6 . It has not escaped our attention that other ways of weighing the scores of line of evidence may give slightly different results in terms of prioritization, if not in terms of the list of genes per se.
Nevertheless, we feel this simple scoring system provides a good separation and prioritization of genes and blood biomarkers that may be disease relevant, which is our stated focus.

Pathway analyses. Ingenuity 8.0 (Ingenuity Systems, Redwood City, CA, USA) was employed to analyze the molecular networks, biological functions and canonical pathways of the DHA-modulated genes, as well as identify which genes modulated by DHA are also the target of existing drugs.

\section{Results}

\section{Effects of DHA on mood-related behavioral measures in DBP KO mice}

Activity levels. DBP $(+/+) \mathrm{WT}$ and DBP $(-/-) \mathrm{KO}$ mice on a diet either low or high in DHA were subjected to a chronic stress paradigm consisting of isolation (single housing) for 28 days, with an acute stressor (behavioral challenge tests, including FST) at day 21 . On day 28 , we measured locomotion in open field. Two- factor analysis of variance was carried out (genotype $\times$ diet) for FST and Open Field Locomotion.

The FST is a standard test used to measure mood state and response to antidepressant medications in rodents. In female mice (Figure 1), we observed a significant decrease in immobility in the depressed-like WT mice, and an increase in immobility in the manic-like $\mathrm{KO}$ mice, on high-DHA diet compared with low-DHA diet. In other words, DHA supplementation seemed to normalize mood state, acting as a mood-stabilizing agent. A slight trend toward reducing immobility in WT male mice was also observed.

Open Field Locomotion is a test that is used as a surrogate for mood state, by extrapolation from human behaviors, with higher locomotion corresponding to higher mood, and lower locomotion to lower mood. In male mice (Figure 1), we observed a significant decrease in locomotion in the maniclike $\mathrm{KO}$ mice, and a trend to increased locomotion in the depressed-like WT mice, on high-DHA diet compared with low-DHA diet. Again, DHA supplementation seemed to normalize mood state. Similar trends that did not reach significance were observed in female mice.

Two independent behavioral measures related to mood were normalized by DHA treatment, with interesting gender differences observed. The FST was more significantly changed in female mice, and the open field locomotion in male mice. Similar gender-related differences in behavior have also been reported in other animal models of mood disorders, ${ }^{32}$ and may be reflective of human gender differences in mood phenotypes. ${ }^{33,34}$

PhenoChipping. An unsupervised two-way hierarchical clustering of the mouse open field locomotor behavioral data measures (phenes) using GeneSpring was carried out ${ }^{22}$ (Supplementary Figure S1). Male stressed (ST) DBP KO mice on the high-DHA diet and male ST DBP KO mice on the low-DHA diet clustered into two distinct groups. Similar to our previous results for male ST DBP KO vs non-ST DBP KO 


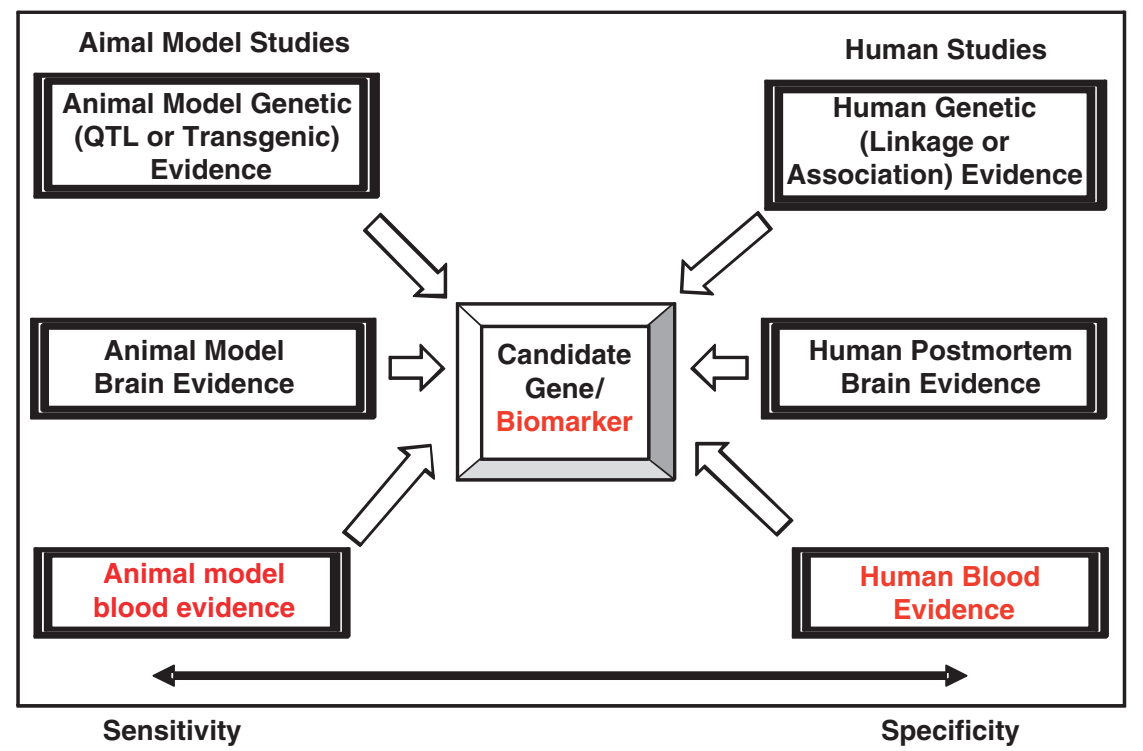

Figure 2 Convergent functional genomics (CFG). Bayesian integration of multiple animal model and human lines of evidence to prioritize disease-relevant genes.

male mice, ${ }^{22}$ Resting Time was the phene most different between male ST DBP KO mice on high- vs low-DHA diet, being increased in the high-DHA diet group. Center Time (time spent in the center quadrant of the open field), was decreased in mice on the high- vs low-DHA diet. A decrease in Center Time may correlate with a decrease in risk-taking behavior or increased anxiety, as mice generally avoid the potentially dangerous, center area of an open field. Female mice did not separate into two distinct clusters.

Food intake. Food is a hedonic stimulus in mice, and the high-DHA diet may be more appetitive than the low-DHA diet because of higher fat content. Total food intake displayed a minimal trend toward increase in high-DHA vs low-DHA diet, irrespective of genotype. The weight changes were in a similar direction, with the notable exception of female DBP WT mice where there was less increase in weight despite increased food intake (Supplementary Figure S2).

\section{Gene expression effects of omega-3 fatty acids in DBP KO mice}

Top genes. At the top of our list for disease-relevant genes modulated by DHA in female mice brain (Tables 1 and 2 and Figure 3) are genes such as GSK3B (in PFC), DRD2 and $P P P 1 R 1 B / D A R R P P-32$ (in the AMY) and GRIA2 (in HIP). GSK3B (glycogen synthase kinase $3 \beta$ ) has consistent signals in genome-wide association studies of bipolar disorder. ${ }^{35}$ GSK3B expression is decreased in mouse PFC by $\mathrm{DHA}$, whereas it is increased in post-mortem human brain in depression. ${ }^{36}$ Of note, one of the gold standard moodstabilizing medications for bipolar disorder, lithium, is a GSK3B inhibitor. ${ }^{37}$ DRD2 (dopamine receptor 2) is a main target for numerous antipsychotic medications (Table 5), and PPP1R1B/DARPP-32 (protein phosphatase 1, regulatory (inhibitor) subunit 1B/dopamine- and cAMP-regulated phosphoprotein, $32 \mathrm{kDa}$ ) is at the nexus of signaling pathways by antidepressants and other psychotropic drugs. ${ }^{38}$ GRIA2 (glutamate receptor, ionotropic, AMPA2) is associated with bipolar disorder, ${ }^{39}$ and has been reported to be increased in expression in human post-mortem brain from bipolars ${ }^{40}$ and from suicides, ${ }^{41}$ whereas DHA decreases the expression in mouse HIP.

At the top of our list for disease-relevant genes modulated by DHA in male mice brain (Tables 1 and 2 and Figure 3 ) are genes such as FOS, GABRA1, MBP (in HIP) and PTGDS (in $\mathrm{HIP}$ and PFC). FOS (FBJ osteosarcoma oncogene) is an immediate response gene involved in response to stress and inflammation. FOS is decreased in the mouse PFC by DHA, an effect in opposite direction to the increase seen in postmortem brains of bipolar subjects, ${ }^{42}$ and in blood cells of subjects with stress disorders. ${ }^{43,44}$ GABRA1 ( $\gamma$-aminobutyric acid (GABA) A receptor, subunit $\alpha 1$ ) is associated with bipolar disorder. ${ }^{45,46}$ It is decreased in expression in brains from animal models of alcoholism and stress, whereas DHA increases its expression in DBP mouse HIP. PTGDS (prostaglandin D2 synthase; brain) is associated with anxiety, ${ }^{47}$ and is decreased in expression in human post-mortem brain from bipolars ${ }^{48}$ as well as in animal models of anxiety ${ }^{49}$ and stress, ${ }^{50}$ whereas DHA increases its expression in the PFC and HIP of DBP KO mice.

Last but not least, MBP (myelin basic protein) is associated with bipolar disorder, and is decreased in expression in human post-mortem brain from bipolars ${ }^{51}$ and from suicides, ${ }^{41}$ whereas DHA increases its expression in mouse HIP. Interestingly, a whole series of other myelin-related genes were increased in expression by DHA in DBP male mice (CNP, MOBP, PLP1, MOG) and female mice (MAL, PLP1). Myelin-related gene expression decrease is a common, if nonspecific, denominator of neuropsychiatric disorders, ${ }^{51,52}$ and is modeled by the non-DHA-treated DBP KO mice. ${ }^{22}$ To our knowledge, DHA is the only compound to date to 


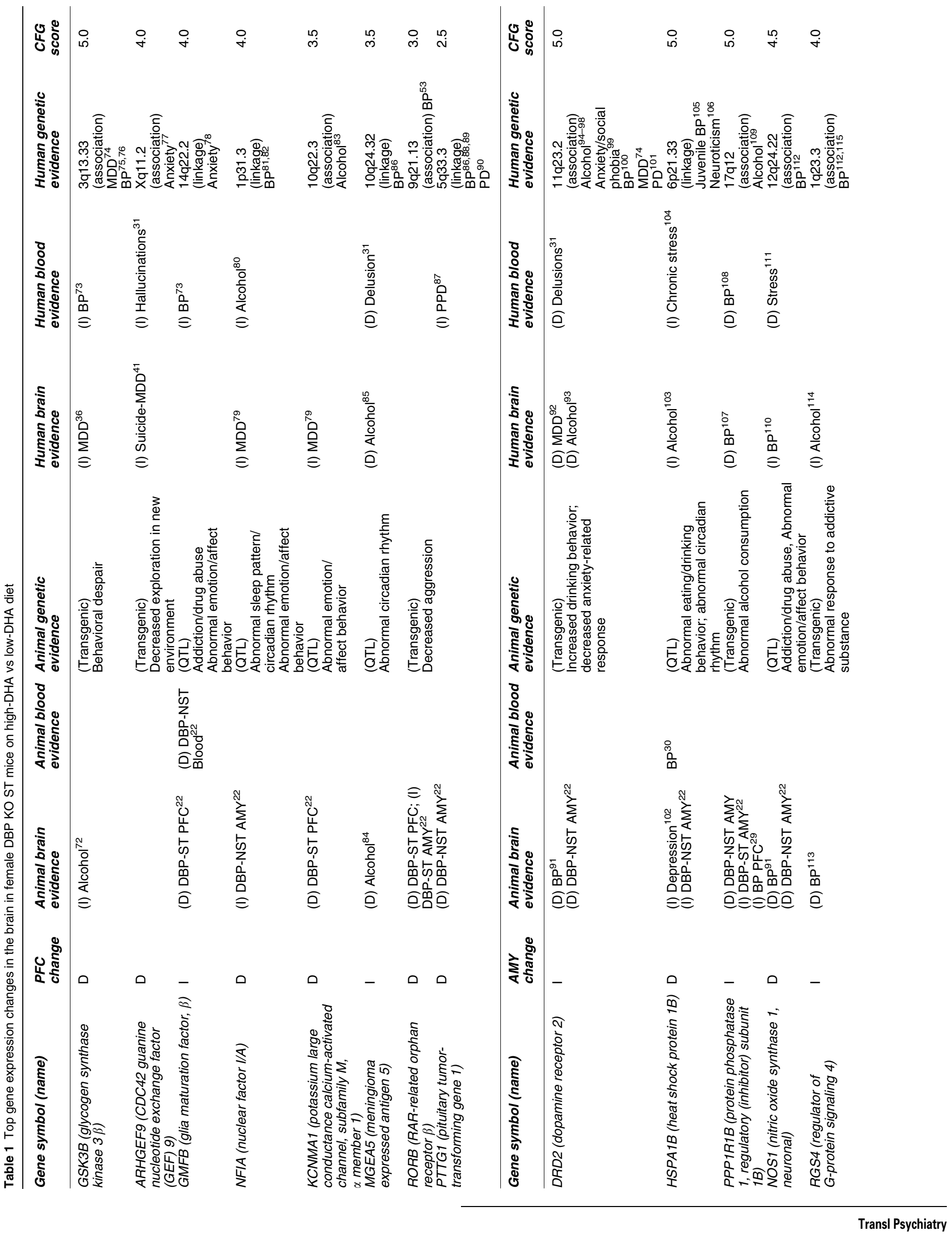




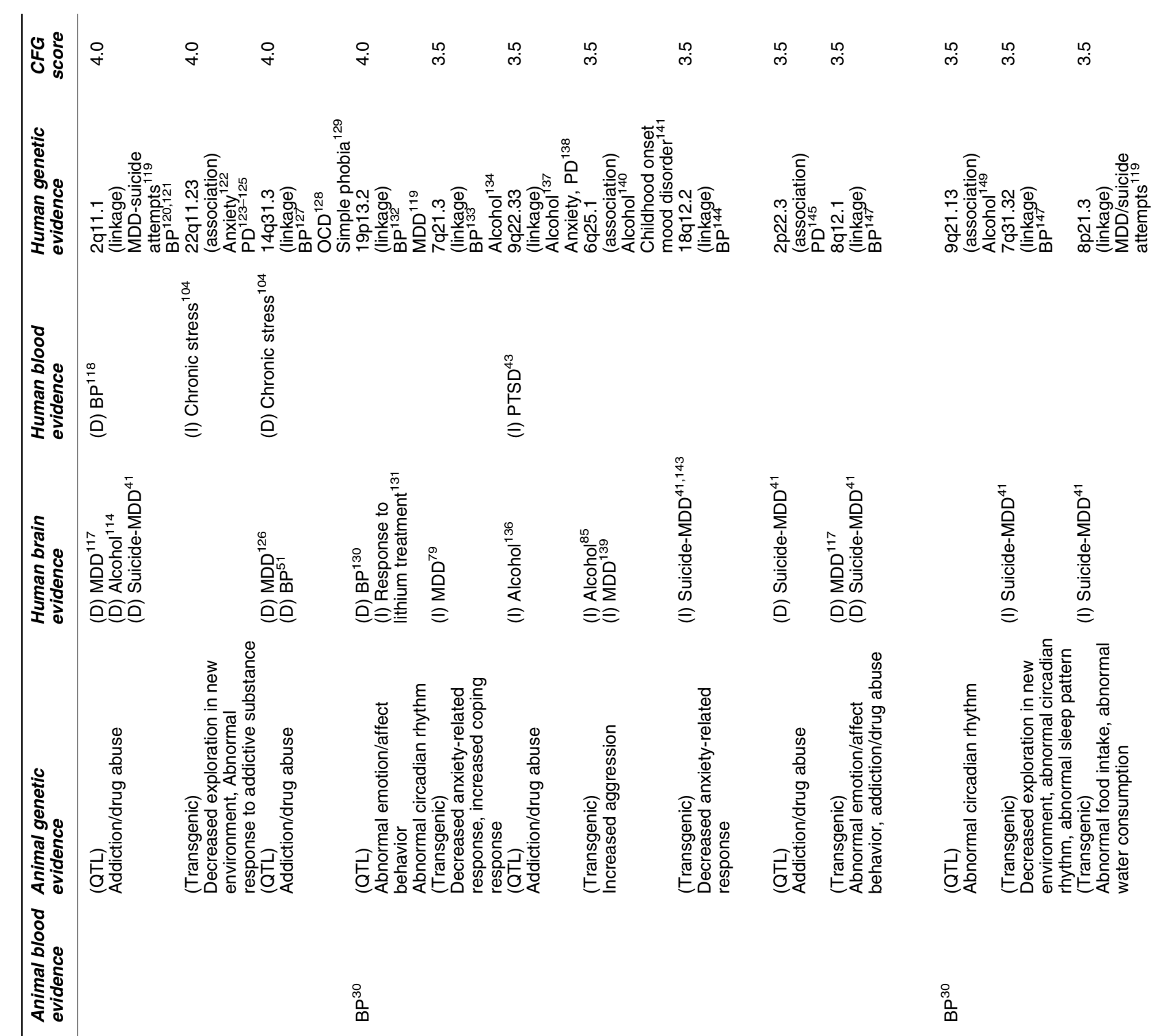

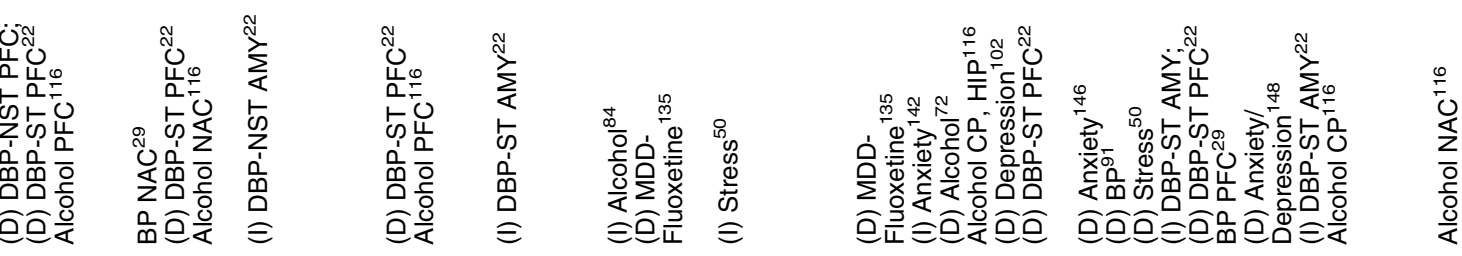




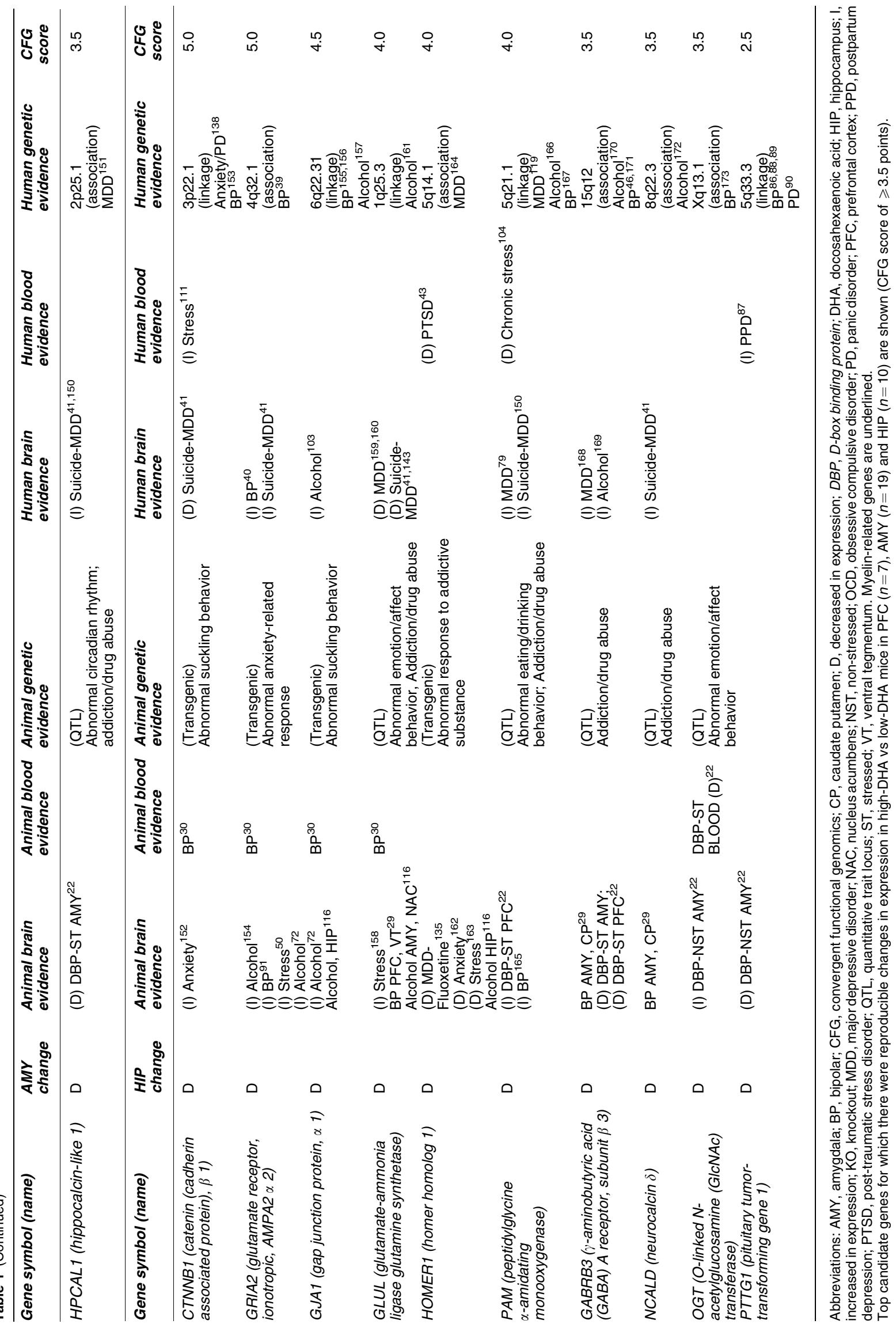




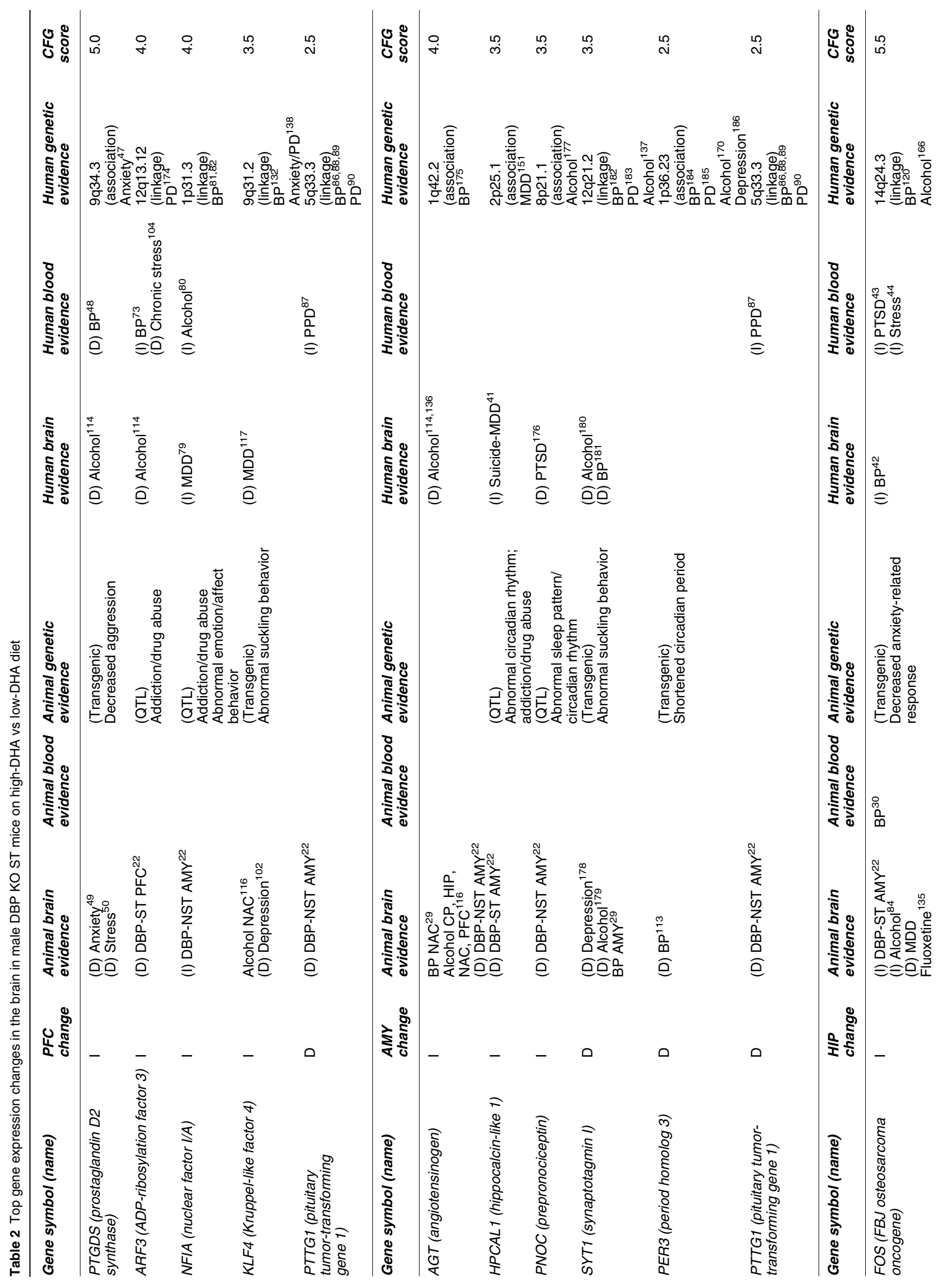




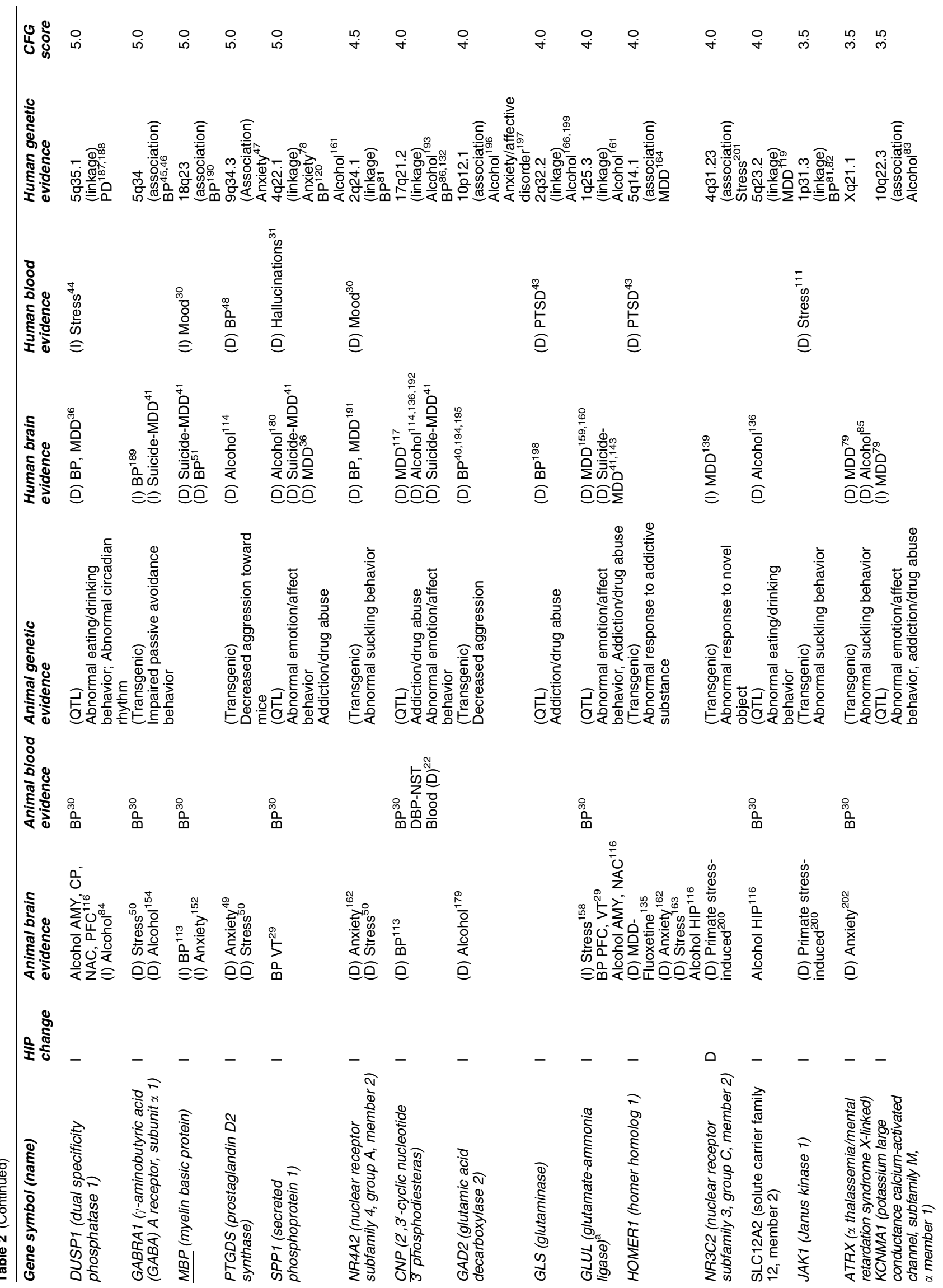




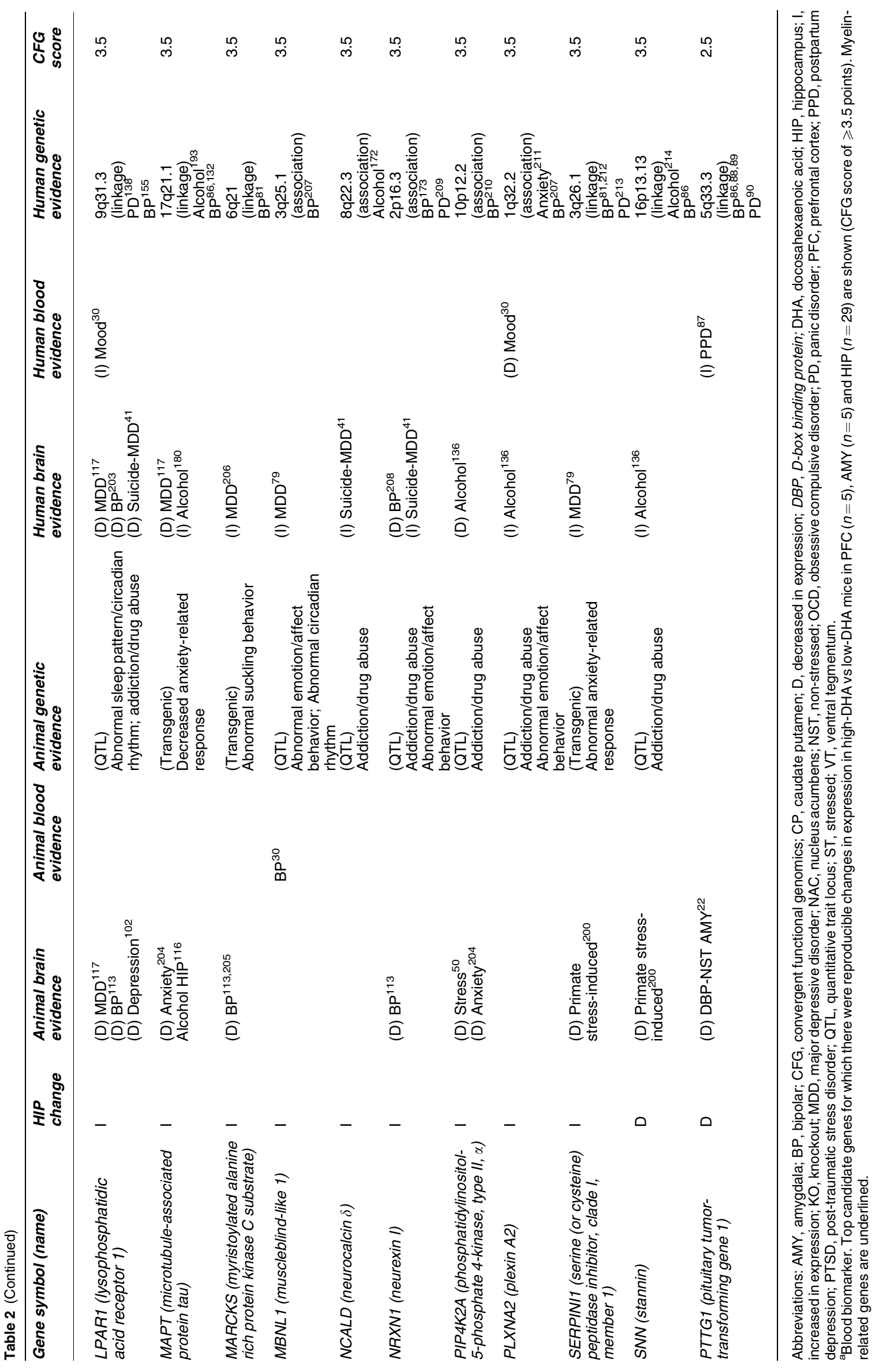




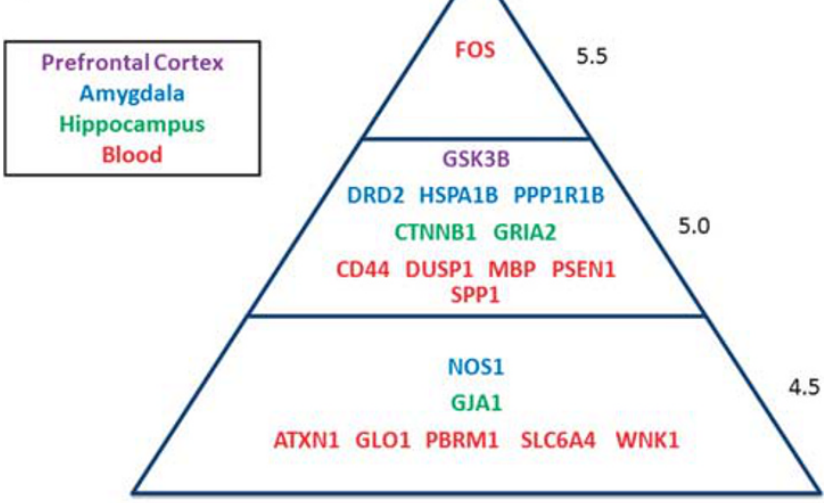

b

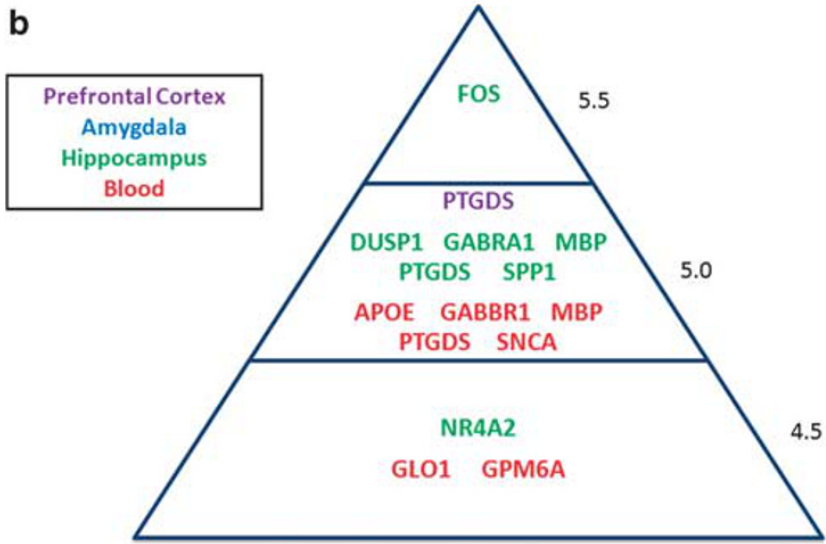

Figure 3 Top candidate genes changed in DBP knockout (KO) stressed (ST) mice on high- vs low-docosahexaenoic acid (DHA) diet. (a) Female mice and (b) male mice.

demonstrate such a powerful broad effect on myelin-related genes, and potentially reverse this pathology.

Sex differences and similarities at gene and pathway levels. There are profound sex differences, that is, there is little overlap, at individual gene levels, between the changes induced by DHA in males and in females. For example, in $\mathrm{HIP}$, only five genes are changed in the same direction in males and females: PTTG1 and ADI1 (decreased by DHA) and $S C D, H B A-A 1$ and $H B B-B 1$ (increased by DHA). PTTG1 (pituitary tumor transforming gene 1) is also decreased in all three male brain regions analyzed (PFC, AMY and HIP). PTTG1 is an oncogene involved, among other things, in pituitary tumors. Its downregulation by DHA is indicative of potential anticancer benefits of DHA treatment that merit future exploration. However, at a pathway level, there is more overlap between males and females. For example, two of the five top five canonical pathways in HIP (glutamate receptor signaling, GABA receptor signaling) are shared between males and females, although different genes in these pathways are changed in each sex (Table 3b). Inflammation-related pathways are prominent in the PFC, and signaling pathways (cyclic adenosine monophosphate in females and circadian rhythm in males) in the AMY (Tables $3 a$ and $b$ ).
Table 3 Ingenuity pathway analysis of the genes changed in DHA-treated mice: analysis of all differentially expressed genes in (a) female mice and (b) male mice

\begin{tabular}{lrr}
\hline Pathways & P-value & Ratio \\
\hline (a) & & \\
Top canonical pathways, female PFC ( $\mathrm{n}=66$ genes) & \\
Primary immunodeficiency signaling & $2.59 \mathrm{E}-08$ & $6 / 63(0.095)$ \\
B-cell development & $1.41 \mathrm{E}-07$ & $5 / 37(0.135)$ \\
Communication between innate and & $2.49 \mathrm{E}-04$ & $4 / 107(0.037)$ \\
adaptive immune cells & & \\
Autoimmune thyroid disease signaling & $6.39 \mathrm{E}-04$ & $3 / 61(0.049)$ \\
Systemic lupus erythematosus signaling & $1.52 \mathrm{E}-03$ & $4 / 163(0.025)$ \\
& & \\
Top canonical pathways, female AMY $(\mathrm{n}=150$ genes) & \\
cAMP-mediated signaling & $3.54 \mathrm{E}-07$ & $10 / 161(0.062)$ \\
G-protein-coupled receptor signaling & $6.51 \mathrm{E}-07$ & $11 / 222(0.05)$ \\
Relaxin signaling & $9.52 \mathrm{E}-06$ & $8 / 151(0.053)$ \\
Cardiac $\beta$-adrenergic signaling & $4.27 \mathrm{E}-04$ & $6 / 142(0.042)$ \\
Protein kinase A signaling & $5.61 \mathrm{E}-04$ & $9 / 318(0.028)$ \\
& & \\
Top canonical pathways, female HIP $(\mathrm{n}=103$ genes) & \\
Glutamate receptor signaling & $2.67 \mathrm{E}-04$ & $4 / 70(0.057)$ \\
Polyamine regulation in colon cancer & $2.62 \mathrm{E}-03$ & $2 / 22(0.091)$ \\
GABA receptor signaling & $2.49 \mathrm{E}-02$ & $2 / 55(0.036)$ \\
Mitotic roles of polo-like kinase & $3.27 \mathrm{E}-02$ & $2 / 62(0.032)$ \\
TR/RXR activation & $7.64 \mathrm{E}-02$ & $2 / 99(0.02)$ \\
& &
\end{tabular}

(b)

Top canonical pathways, male PFC ( $\mathrm{n}=77$ genes

CCR5 signaling in macrophages

Clathrin-mediated endocytosis signaling $\quad 2.52 \mathrm{E}-02 \quad 3 / 169(0.018)$

IL-8 signaling

BMP signaling pathway

Pathogenesis of multiple sclerosis $\quad 3.49 \mathrm{E}-02$

$3 / 188(0.016)$

$2 / 80(0.025)$

$1 / 9(0.111)$

Top canonical pathways, male AMY $(\mathrm{n}=59$ genes

Neuroprotective role of THOP1 in $\quad 4.16 \mathrm{E}-03 \quad 2 / 54(0.037)$

Alzheimer's disease

Glycine, serine and threonine metabolism 2.48E-02 2/150 (0.013)

Glycerophospholipid metabolism $\quad 4.55 \mathrm{E}-02 \quad 2 / 192(0.01)$

$\begin{array}{lll}\text { RAR activation } & 4.96 \mathrm{E}-02 & 2 / 181(0.011)\end{array}$

Top canonical pathways, male HIP ( $\mathrm{n}=352$ genes)

Aldosterone signaling in epithelial cells $\quad 1.97 \mathrm{E}-05 \quad 9 / 97(0.093)$

Glutamate receptor signaling $\quad 7.12 \mathrm{E}-04 \quad 6 / 70(0.086)$

GABA receptor signaling $\quad 1.51 \mathrm{E}-03 \quad 5 / 55(0.091)$

RAR activation $\quad 2.22 \mathrm{E}-03 \quad 9 / 181(0.05)$

14-3-3-mediated signaling $\quad 2.89 \mathrm{E}-03 \quad 7 / 116(0.06)$

Abbreviations: AMY, amygdala; BMP, bone morphogenetic protein; cAMP, cyclic AMP: CCR5, chemokine (C-C motif) receptor 5; $\mathrm{DHA}$, docosahexaenoic acid; GABA, g-aminobutyric acid; HIP, hippocampus; IL, interleukin; PFC, prefrontal cortex; RAR, retinoic acid receptor; RXR, retinoid X receptor; THOP1, thimet oligopeptidase 1; TR, thyroid hormone receptor.

Circadian clock genes are also being modulated by DHA, with PER3 (period homolog 3) being decreased in expression in the AMY of males, and RORB (RAR-related orphan receptor $\beta$ ) decreased in expression in PFC of females. Of note, we have previously reported evidence for genetic association of $R O R B$ with bipolar disorder in a pediatric bipolar cohort. ${ }^{53}$

Blood biomarkers. RAB27B (from AMY), and CAP1, CAPZB, GNG2, KLF9, NDUFS5, SSX2IP and VPS13A (from HIP) are co-regulated in the same direction in brain and blood of DBP female mice by DHA (Table 4a). For male mice, TFRC (from PFC), CD24A and FTL1 (from AMY), GLUL, LIMD2, PSME4 and TTR (in HIP) are co-regulated in the same direction in brain and blood by DHA (Table $4 b$ ). 


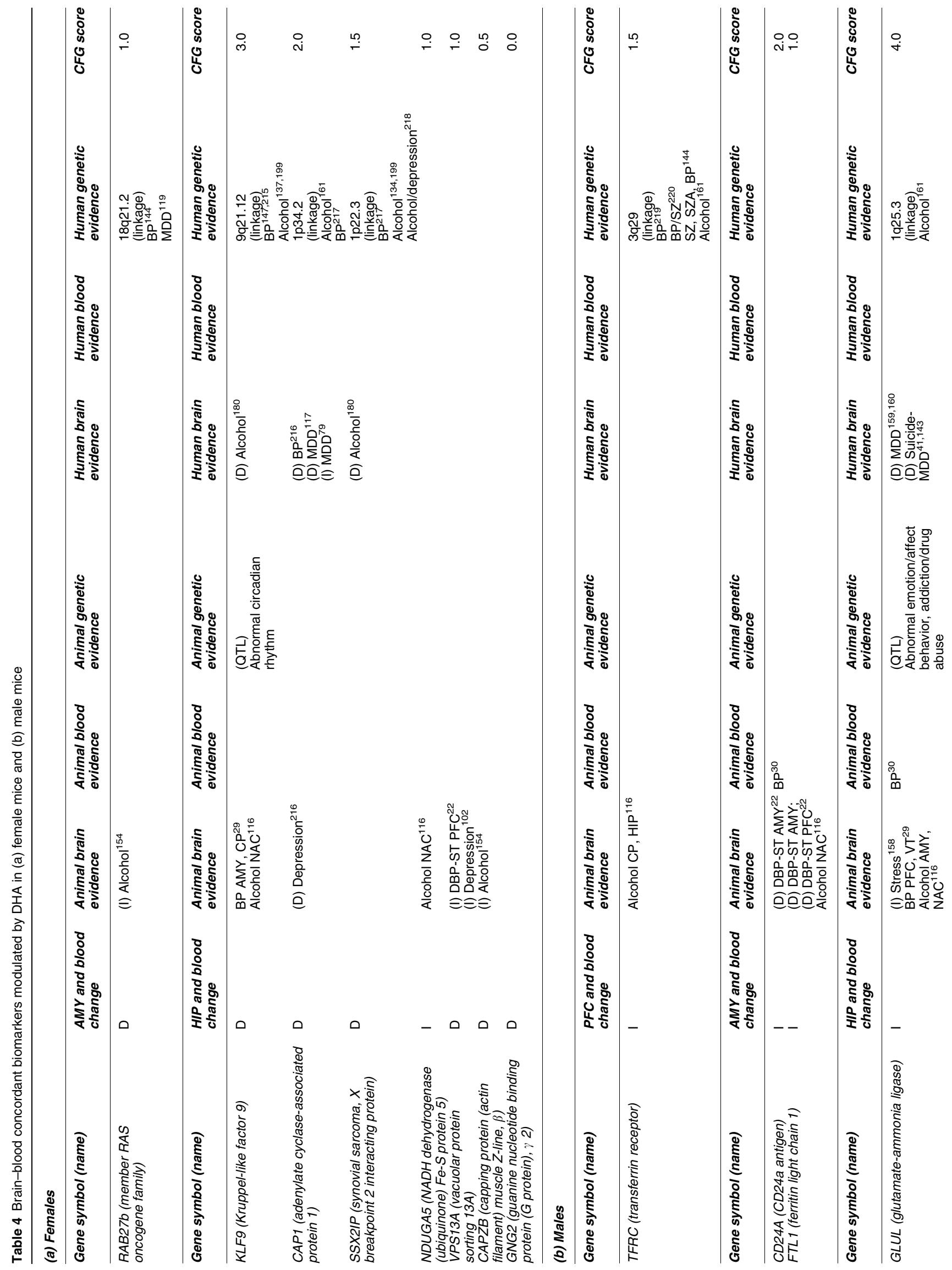


These genes warrant further studies in human clinical populations as potential gender-specific peripheral biomarkers of DHA treatment response.

In addition, a number of other genes are changed in expression by DHA in DBP mouse blood in opposite direction to that seen in human blood in mood disorders and stress disorders (Supplementary Tables S1 and S2). Although not changed in the same direction in the DBP mouse brain, at least in the limited numbers of regions we have assayed so far, they may nevertheless be viable human biomarkers of the therapeutic effects of DHA, upon further study and validation. Notably, one of these candidate markers is SLC6A4 (solute carrier family 6 (neurotransmitter transporter, serotonin), member 4), decreased in expression by DHA in female DBP mouse blood.

Drugs that exert similar effects to DHA. A number of DHA-responsive genes identified by us in mice are modulated by existing drugs (Table 5), notably antipsychotics, benzodiazepines, calcium channel blockers and estrogens in females, respectively valproic acid and ketamine in males. Those classes of medications have a history of mood-modulating effects, use and abuse in bipolar and co-morbid disorders. Recent work has also shown that lithium can modulate DHA metabolism. ${ }^{54}$

\section{Effects of DHA on alcohol consumption in two independent animal models: DBP KO mice and alcohol-preferring $\mathbf{P}$ rats}

$D B P K O$ mice on high-DHA diet drink less alcohol than $D B P K O$ mice on low DHA. The high rate of co-morbidity between bipolar disorder and alcoholism in humans ${ }^{55}$ is reflected in our DBP $\mathrm{KO}$ mice animal model. We had previously shown that male DBP KO mice subjected to the chronic isolation stress paradigm consume more ethanol than the control DBP WT mice subjected to stress. ${ }^{22}$ We have now tested if a high-DHA diet would impact the alcohol consumption of these DBP KO mice compared with a lowDHA diet. In two separate analyses, one from a 2-week experiment and one from a 4-week experiment, we found that DHA significantly reduces alcohol consumption (Figure 4). No significant differences in water consumption were observed (data not shown), which shows that mice are showing a preference for alcohol, and not simply drinking more fluids.

$P$ rats on high-DHA diet drink less alcohol than $P$ rats on low-DHA diet. We were able to reproduce our findings in a well-established, independent animal model of alcohol consumption, the alcohol-preferring $P$ rats. These rats are also subjected to single housing, which may induce chronic stress. Additionally, for these experiments, we did not just look at extremes of diet in terms of DHA content, but also used a normal control diet, with an intermediate content of DHA. A dose-dependent effect was observed, where alcohol-preferring $\mathrm{P}$ rats on a diet high in DHA drank significantly less alcohol over a 14-day period than did $P$ rats on a normal control diet, and rats on a diet low in DHA (Figure 5). 
Table 5 DHA-responsive genes in our data set that are the targets of existing drugs

(a) Females

\begin{tabular}{l}
\hline Gene symbol (name) \\
\hline PFC \\
GSK3B (glycogen synthase kinase $3 \beta$ ) \\
KCNMA1 (potassium large conductance \\
calcium-activated channel, subfamily $M$, \\
$\alpha$ member 1 ) \\
AMY \\
DRD2 (dopamine receptor D2)
\end{tabular}

G-protein-coupled receptor

NOS1 (nitric oxide synthase 1) (neuronal) Enzyme ALDH1A1 (aldehyde dehydrogenase 1 Enzyme family, member A1) ESR1 (estrogen receptor 1)

Ligand-dependent nuclear receptor

GABRD ( $\gamma$-aminobutyric acid (GABA) $A$ receptor, $\delta)$

Ion channel

\section{PDE7B (phosphodiesterase 7B)}

HIP
SCN4B (sodium channel, voltage-gated, type IV, $\beta$ )

GRIA2 (glutamate receptor, ionotropic, AMPA 2)

GABRB3 ( $\gamma$-aminobutyric acid

(GABA) A receptor, $\beta$ 3)

Enzyme

Ion channel

Ion channel

Ion channel

CACNA2D1 (calcium channel, voltagedependent, $\alpha 2 / \delta$ subunit 1$)$

IFNGR2 (interferon $\gamma$ receptor 2 (interferon $\gamma$ transducer 1))
Ion channel

Transmembrane receptor
Drug(s)

CFG

score

Enzastaurin

Tedisamil

5.0

3.5

- $\alpha$-ethinylestradiol, fulvestrant, $\beta$-estradiol, estradiol $17-\beta-$ cypionate, estrone, estradiol valerate, 3-(4-methoxy)phenyl-4((4-(2-(1-piperidinyl)ethoxy)phenyl)methyl)-2H-1-benzopyran7-ol, bazedoxifene, estradiol valerate/testosterone enanthate, TAS-108, ethinyl estradiol/ethynodiol diacetate, estradiol acetate, esterified estrogens, estradiol cypionate/ medroxyprogesterone acetate, conjugated estrogens/ meprobamate, estradiol/norethindrone acetate, synthetic conjugated estrogens

Pagoclone, alphadolone, SEP 174559, tracazolate, sevoflurane, isoflurane, gaboxadol, felbamate, etomidate, muscimol, halothane, fluoxetine/olanzapine, eszopiclone, temazepam, zolpidem, lorazepam, olanzapine, clonazepam, zaleplon, secobarbital, phenobarbital, pentobarbital, D 23129 , desflurane, methoxyflurane, enflurane, pregnenolone

Dyphylline, nitroglycerin, aminophylline, anagrelide, milrinone, dipyridamole, tolbutamide, theophylline, pentoxifylline Riluzole

Talampanel, Org 24448, LY451395, tezampanel

Methohexital, aspirin/butalbital/caffeine, aspirin/butalbital/ caffeine/codeine, pagoclone, alphadolone, SEP 174559, acetaminophen/butalbital/caffeine, sevoflurane, isoflurane, gaboxadol, isoniazid, felbamate, etomidate, muscimol, halothane, fluoxetine/olanzapine, amobarbital, atropine/ hyoscyamine/phenobarbital/scopolamine, acetaminophen/ butalbital, eszopiclone, mephobarbital, hyoscyamine/ phenobarbital, acetaminophen/butalbital/caffeine/codeine, butabarbital, temazepam, zolpidem, lorazepam, olanzapine, clonazepam, zaleplon, secobarbital, butalbital, phenobarbital, pentobarbital, thiopental, D 23129, desflurane,

methoxyflurane, enflurane, pregnenolone

Amlodipine/valsartan/hydrochlorothiazide, amlodipine/

Amisartan, bepridil, amlodipine, pregabalin

Interferon $\gamma$-1b

\section{(b) Males}

PFC

COL6A2 (collagen, type $\mathrm{VI}, \alpha 2$ )

CCR5 (chemokine (C-C motif) receptor 5)

Other

G-protein-coupled

Collagenase clostridium histolyticum

Maraviroc, vicriviroc, SCH 351125

receptor

\section{$A M Y$}

GRIN2C (glutamate receptor, ionotropic, Ion channel $N$-methyl D-aspartate 2C)
4.5

3.5

3.5
Dextromethorphan/guaifenesin, morphine/dextromethorphan, neramexane, bicifadine, delucemine, CR 2249, besonprodil, UK-240455, ketamine, felbamate, memantine, orphenadrine, cycloserine, $\mathrm{N}$-(2-indanyl)glycinamide, dextromethorphan 
Table 5 (Continued)

\begin{tabular}{|c|c|c|c|}
\hline \multicolumn{4}{|l|}{ (b) Males } \\
\hline Gene symbol (name) & Type(s) & $\operatorname{Drug}(\mathbf{s})$ & $\begin{array}{l}\text { CFG } \\
\text { score }\end{array}$ \\
\hline \multicolumn{4}{|l|}{ HIP } \\
\hline $\begin{array}{l}\text { GABRA1 ( } \gamma \text {-aminobutyric acid (GABA) A } \\
\text { receptor, } \alpha 1)\end{array}$ & Ion channel & $\begin{array}{l}\text { Methohexital, aspirin/butalbital/caffeine, aspirin/butalbital/ } \\
\text { caffeine/codeine, pagoclone, alphadolone, SEP 174559, } \\
\text { acetaminophen/butalbital/caffeine, sevoflurane, isoflurane, } \\
\text { gaboxadol, isoniazid, felbamate, etomidate, muscimol, } \\
\text { halothane, fluoxetine/olanzapine, amobarbital, estazolam }\end{array}$ & 5.0 \\
\hline GAD2 (glutamate decarboxylase 2) & Enzyme & Valproic acid & 4.0 \\
\hline $\begin{array}{l}\text { NR3C2 (nuclear receptor subfamily } 3 \text {, } \\
\text { group } C \text {, member } 2 \text { ) }\end{array}$ & $\begin{array}{l}\text { Ligand-dependent } \\
\text { nuclear receptor }\end{array}$ & $\begin{array}{l}\text { Hydrochlorothiazide/spironolactone, fludrocortisone acetate, } \\
\text { drospirenone, spironolactone, eplerenone }\end{array}$ & 4.0 \\
\hline $\begin{array}{l}\text { SLC12A2 (solute carrier family } 12 \\
\text { (sodium/potassium/chloride transporters), } \\
\text { member 2) }\end{array}$ & Transporter & Bumetanide & 4.0 \\
\hline $\begin{array}{l}\text { KCNMA1 potassium large conductance } \\
\text { calcium-activated channel, subfamily } M \text {, } \\
\alpha \text { member } 1\end{array}$ & Ion channel & Tedisamil & 3.5 \\
\hline $\begin{array}{l}\text { ATP1A2 (ATPase, } \mathrm{Na}+/ \mathrm{K}+\text { transporting, } \\
\alpha 2 \text { polypeptide) }\end{array}$ & Transporter & Digoxin, omeprazole, ethacrynic acid, perphenazine & 2.5 \\
\hline LPL (lipoprotein lipase) & Enzyme & Nicotinic acid, lovastatin/niacin & 2.0 \\
\hline $\begin{array}{l}S L C 1 A 3 \text { (solute carrier family } 1 \text { (glial high } \\
\text { affinity glutamate transporter), member } 3 \text { ) }\end{array}$ & Transporter & Riluzole & 2.0 \\
\hline $\begin{array}{l}\text { SLC6A1 (solute carrier family } 6 \\
\text { (neurotransmitter transporter, GABA), } \\
\text { member 1) }\end{array}$ & Transporter & Tiagabine & 2.0 \\
\hline $\begin{array}{l}\text { CHUK (conserved helix-loop-helix } \\
\text { ubiquitous kinase) }\end{array}$ & Kinase & Methyl 2-cyano-3,12-dioxoolean-1,9-dien-28-oate & 1.0 \\
\hline PARP1 (poly (ADP-ribose) polymerase 1) & Enzyme & ABT-888, INO-1001 & 1.0 \\
\hline $\begin{array}{l}\text { SCN1A (sodium channel, voltage-gated, } \\
\text { type I, a subunit) }\end{array}$ & Ion channel & $\begin{array}{l}\text { Articaine/epinephrine, articaine, bupivacaine/lidocaine, } \\
\text { chloroprocaine, epinephrine/prilocaine, epinephrine/lidocaine, } \\
\text { fosphenytoin, phenytoin, prilocaine, lamotrigine, lidocaine, } \\
\text { riluzole }\end{array}$ & 1.0 \\
\hline TGFB2 (transforming growth factor, $\beta$ 2) & Growth factor & AP-12009 & 1.0 \\
\hline $\begin{array}{l}\text { HTR5A (5-hydroxytryptamine (serotonin) } \\
\text { receptor } 5 A)\end{array}$ & $\begin{array}{l}\text { G-protein-coupled } \\
\text { receptor }\end{array}$ & Asenapine & 0.5 \\
\hline $\begin{array}{l}\text { SCN8A (sodium channel, voltage gated, } \\
\text { type VIII, } \alpha \text { subunit) }\end{array}$ & Ion channel & Riluzole & 0.5 \\
\hline
\end{tabular}

Abbreviations: AMY, amygdala; CFG, convergent functional genomics; DHA, docosahexaenoic acid; HIP, hippocampus; PFC, prefrontal cortex. Ingenuity analyses of the genes that are targeted by existing drugs.

\section{Discussion}

We conducted integrative studies of DHA treatment in animal models as a way of validating the efficacy of DHA as a psychotropic agent, to understand its underlying molecular effects in the brain, and to identify potential blood biomarkers of treatment response. Our work provides evidence on all three counts. Moreover, it identifies a previously unsuspected effect of DHA on decreasing alcohol consumption, which we substantiated in two independent animal models.

DBP KO ST mice as a human disease-relevant animal model. First, the behavioral phenomenology and inferences from molecular changes in the DBP $\mathrm{KO}$ mice revealed by our previous work ${ }^{22}$ bear broad similarities to the DSM (Diagnostic and Statistical Manual of Mental Disorders) criteria for bipolar disorder. Moreover, their switch in phenotype is a cardinal aspect of the human condition. As such, DBP KO mice are arguably one of the first comprehensive genetic animal models of bipolar disorder to be described, complementing earlier elegant pharmacological and genetic manipulations that mimic more restricted endophenotypic aspects of the disorder. ${ }^{19,29,56-65}$ The fact that DBP is a transcription factor directly and indirectly regulating many other genes may explain the surprisingly comprehensive mimicry of a putative polygenic human disorder by a single gene ablation in mouse. Some of the genes identified may be directly regulated by DBP through promoter binding, whereas others may be regulated indirectly by a cascade of gene expression changes set in motion by DBP. Moreover, DBP is a circadian clock regulator, and an emerging body of work $^{53,66-68}$ substantiates the role of clock genes in bipolar and related disorders.

The DBP $\mathrm{KO}$ mice are a constitutive $\mathrm{KO}$, and there is always the possibility that compensatory changes can occur during development that may obscure the direct effects of DBP deletion. However, of note, this is a very good equivalent of the human bipolar disorder genetic scenario, where most mutations are likely constitutive rather than acquired, as reflected in the familial inheritance of the disorder. Second, our mice colony is on a mixed genetic background, generated by heterozygote breeding, not on a back-crossed pure mouse-strain background. Although this introduces epistatic 

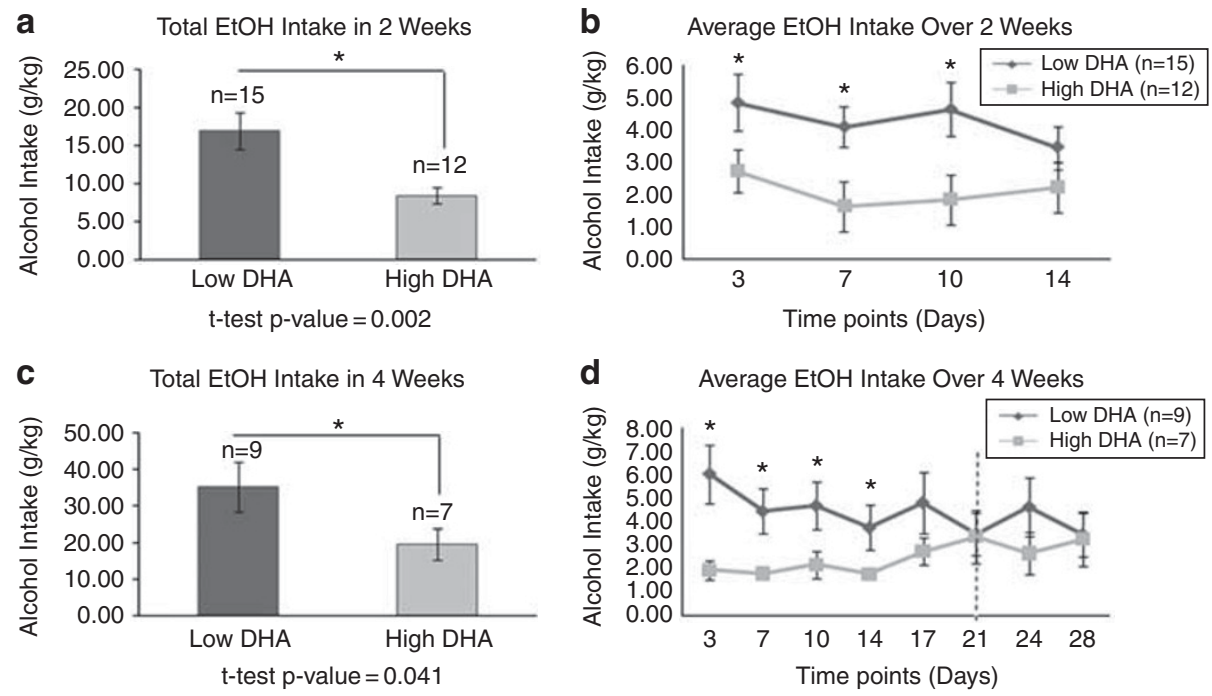

Figure 4 Effects of docosahexaenoic acid (DHA) on male DBP knockout (KO) stressed (ST) mice alcohol (EtOH) consumption: mice on a diet supplemented with either low or high DHA were subjected to alcohol free-choice drinking paradigm. (a, b) Fluid consumption (water or $10 \%$ ethanol) monitored for a period of 2 weeks (14 days). (c, d) Fluid consumption (water or $10 \%$ ethanol) monitored for a period of 4 weeks (28 days) with an acute stressor (behavioral challenge tests represented by the dotted vertical line) at day 21 , as described in the Materials and methods Section. ${ }^{*} P<0.05$.
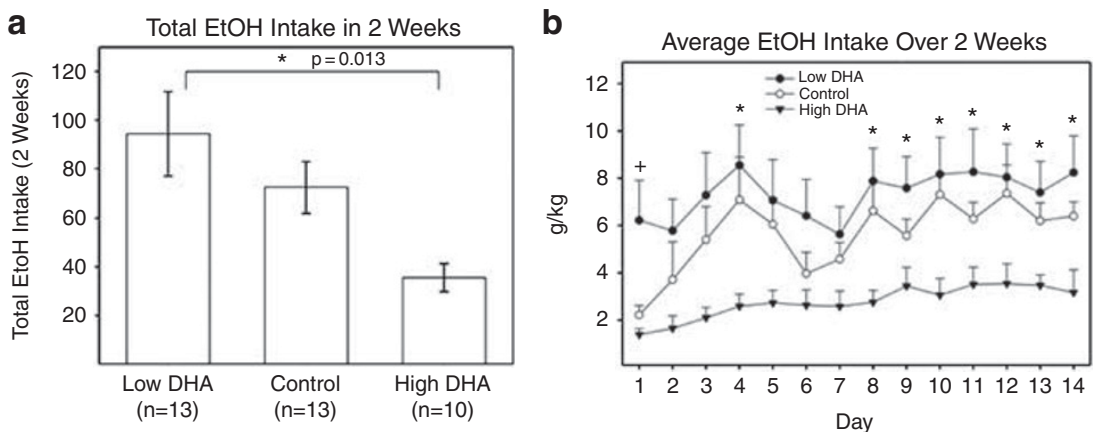

Figure 5 Effects of docosahexaenoic acid (DHA) on alcohol (EtOH) consumption in male alcohol-preferring $(\mathrm{P})$ rats. Experimentally naive, male $\mathrm{P}$ rats, 4-6 months of age at the start of the experiment, were used as subjects. These rats were placed on one of the three diets: (1) low-DHA diet, (2) control diet or (3) high-DHA diet. Rats were given continuous free-choice access in the home cage to $15 \% \mathrm{v} / \mathrm{v}$ ethanol and water. Ethanol intake was measured daily throughout the experiment. (a, b) Fluid consumption from both bottles was monitored for a period of 2 weeks (14 days). "t-test $P<0.05$ for rats on low-DHA compared with rats on high-DHA diet.

variability, it is remarkable that the phenotype remains penetrant across generations and cohorts of mice. Again, however, this is a better model of the human condition, which occurs at a population level in a mixed genetic background, than deriving conclusions from a very particular strain of mice.

Stress is an important trigger of medical and mental illness episodes in humans. Acute overwhelming stress (accidents, illness, loss of employment) on top of the chronic stress of social isolation often precede decompensation in bipolar patients ${ }^{69}$ and relapse into alcoholism. ${ }^{70}$ With that in mind, our mice were subjected to a chronic stress paradigm consisting of isolation (single housing) for 1 month, overlaid with an acute stressor (a series of behavioral challenge tests) at the end of the third week of isolation.

Last, the insights into overlapping phenomics, genomics and biomarkers among bipolar, alcoholism, stress and related disorders provided by this mouse model recapitulates in a translational fashion to the issues of complexity, heterogene- ity, overlap and interdependence of major psychiatric syndromes as currently defined by $\mathrm{DSM}^{71}$ that are seen in human patients.

The power of the CFG approach. By cross-validating our animal model gene expression data with other lines of evidence, including human data, we were able to extract a shorter list of genes for which there are external corroborating lines of evidence (human genetic evidence, human post-mortem brain data, human blood data, animal model QTL data) linking them to bipolar and related disorders, thus reducing the risk of false positives. This cross-validation also identifies candidate blood biomarkers that are more likely directly related to the relevant disease neuropathology, as opposed to being potential artifactual effects related to a particular animal cohort or indirect effects of mouse colony environment. The power of our CFG approach is exemplified in the fact that our biomarker 


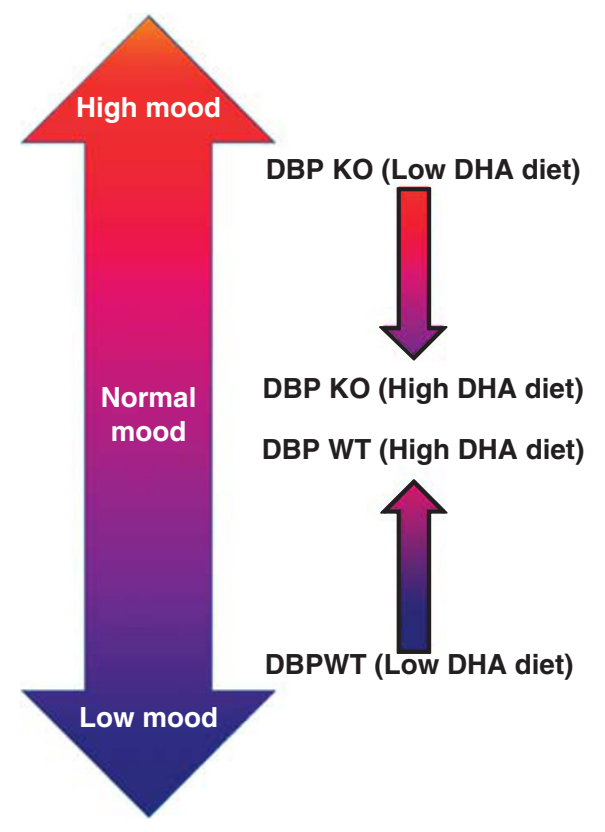

Figure 6 High-docosahexaenoic acid (DHA) diet has a stabilizing effect on mood in stressed mice. A model integrating the behavioral and genomic data.

findings from previous studies have been shown to have good predictive power in independent cohorts, ${ }^{30,31}$ a key litmus test in our view, and one that needs to be applied more systematically in this nascent field. The concordant candidate blood biomarkers for response to DHA that we identified in the current study (notably GLUL (glutamateammonia ligase glutamine synthetase) in males and KLF9 (Kruppel-like factor 9) in females), as well as some of the blood-only candidates that are changed in reverse direction to that seen in human blood in mood and stress disorders (notably SLC6A4 in females, as well as MBP and GLO1 in both sexes), will need to pass that level of scrutiny in future human studies before being deemed of unambiguous value.

From genes and biomarkers to biology. There is little codirectional overlap between the DHA-modulated genes in females and in males identified by us, which is somewhat surprising and quite interesting. However, there is some overlap at a biological pathway level and behavioral level between males and females. A practical implication of this work would be the need to use gender-specific biomarkers of response to treatment. Overall, the model that is emergent from the behavioral and gene expression data is that of DHA acting as a mood-stabilizing agent (Figure 6).

Future studies by us and others may focus on understanding at a mechanistic level the novel uncovered effects on alcohol consumption. We also need to test for potential gender differences in the effects of DHA on alcohol consumption.

Conclusions. Taken together, our convergent results provide evidence that DHA modulates and is involved in molecular networks targeted by current psychotropic medications. They also suggest intriguing possible sex differences for the molecular and behavioral effects of DHA, with a more antidepressant-like profile in females and a more antimanic-like profile in males.

The overall case for using DHA in large-scale human clinical trials and empirical clinical practice as an adjuvant mood-stabilizing agent and a novel potential alcoholism treatment, particularly for co-morbid bipolar disorder and alcoholism, is suggested and beginning to be substantiated at a mechanistic level by our work. Other possible therapeutic effects of DHA (in psychosis, anxiety, stress, pain and substance abuse) are pointed at by some of our data, and existing data in the literature. Given the genetic and biological heterogeneity of psychiatric disorders in human populations, it is possible, indeed likely, that not everyone will respond equally well to DHA treatment. Gender distinctions may be important, as our work suggests. The candidate blood biomarkers identified by us merit hypothesis-driven followup studies as markers of treatment response in a clinical setting; i.e., to test whether they are able to stratify, predict and differentiate early on in treatment responders from nonresponders.

\section{Conflict of interest}

The authors declare no conflict of interest.

Acknowledgements. This work was supported by funds from the Indiana University, NARSAD, a VA Merit Award and a NIH Directors' New Innovator Award to $A B N$.

1. Cunnane SC, Crawford MA. Survival of the fattest: fat babies were the key to evolution of the large human brain. Comp Biochem Physiol A Mol Integr Physiol 2003; 136: 17-26.

2. Simopoulos AP. Evolutionary aspects of diet, the omega-6/omega-3 ratio and genetic variation: nutritional implications for chronic diseases. Biomed Pharmacother 2006; 60: 502-507.

3. DeMar Jr JC, Ma K, Bell JM, Igarashi M, Greenstein D, Rapoport SI. One generation of n-3 polyunsaturated fatty acid deprivation increases depression and aggression test scores in rats. J Lipid Res 2006; 47: 172-180.

4. Rao JS, Ertley RN, Lee HJ, DeMar Jr JC, Arnold JT, Rapoport SI et al. n-3 polyunsaturated fatty acid deprivation in rats decreases frontal cortex BDNF via a p38 MAPK-dependent mechanism. Mol Psychiatry 2007; 12: 36-46.

5. Zanarini MC, Frankenburg FR. Omega-3 Fatty acid treatment of women with borderline personality disorder: a double-blind, placebo-controlled pilot study. Am J Psychiatry 2003; 160: $167-169$.

6. Lin PY, Huang SY, Su KP. A meta-analytic review of polyunsaturated fatty acid compositions in patients with depression. Biol Psychiatry 2010; 68: 140-147.

7. McNamara RK. DHA deficiency and prefrontal cortex neuropathology in recurrent affective disorders. J Nutr 2010; 140: 864-868.

8. McNamara RK, Jandacek R, Rider T, Tso P, Stanford KE, Hahn CG et al. Deficits in docosahexaenoic acid and associated elevations in the metabolism of arachidonic acid and saturated fatty acids in the postmortem orbitofrontal cortex of patients with bipolar disorder. Psychiatry Res 2008; 160: 285-299.

9. Stoll AL, Severus WE, Freeman MP, Rueter S, Zboyan HA, Diamond E et al. Omega 3 fatty acids in bipolar disorder: a preliminary double-blind, placebo-controlled trial. Arch Gen Psychiatry 1999; 56: 407-412.

10. Parker G, Gibson NA, Brotchie H, Heruc G, Rees AM, Hadzi-Pavlovic D. Omega-3 fatty acids and mood disorders. Am J Psychiatry 2006; 163: 969-978.

11. Osher $\mathrm{Y}$, Belmaker $\mathrm{RH}$. Omega-3 fatty acids in depression: a review of three studies. CNS Neurosci Ther 2009; 15: 128-133.

12. Clayton EH, Hanstock TL, Hirneth SJ, Kable CJ, Garg ML, Hazell PL. Reduced mania and depression in juvenile bipolar disorder associated with long-chain omega-3 polyunsaturated fatty acid supplementation. Eur J Clin Nutr 2009; 63: 1037-1040.

13. Peet $\mathrm{M}$, Stokes $\mathrm{C}$. Omega-3 fatty acids in the treatment of psychiatric disorders. Drugs 2005; 65: 1051-1059.

14. Berger GE, Wood SJ, Wellard RM, Proffitt TM, McConchie M, Amminger GP et al. Ethyl-eicosapentaenoic acid in first-episode psychosis. A 1H-MRS study. Neuropsychopharmacology 2008; 33: 2467-2473. 
15. Amminger GP, Schafer MR, Papageorgiou K, Klier CM, Cotton SM, Harrigan SM et al. Long-chain omega-3 fatty acids for indicated prevention of psychotic disorders: a randomized, placebo-controlled trial. Arch Gen Psychiatry 2010; 67: 146-154.

16. Farzaneh-Far R, Lin J, Epel ES, Harris WS, Blackburn EH, Whooley MA. Association of marine omega-3 fatty acid levels with telomeric aging in patients with coronary heart disease. JAMA 2010; 303: 250-257.

17. Muldoon MF, Ryan CM, Sheu L, Yao JK, Conklin SM, Manuck SB. Serum phospholipid docosahexaenonic acid is associated with cognitive functioning during middle adulthood J Nutr 2010; 140: 848-853.

18. Green KN, Martinez-Coria H, Khashwji H, Hall EB, Yurko-Mauro KA, Ellis L et al. Dietary docosahexaenoic acid and docosapentaenoic acid ameliorate amyloid-beta and tau pathology via a mechanism involving presenilin 1 levels. J Neurosci 2007; 27: 4385-4395.

19. Niculescu III AB, Segal DS, Kuczenski R, Barrett T, Hauger RL, Kelsoe JR. Identifying a series of candidate genes for mania and psychosis: a convergent functional genomics approach. Physiol Genomics 2000; 4: 83-91.

20. Rodd ZA, Bertsch BA, Strother WN, Le-Niculescu H, Balaraman Y, Hayden E et al. Candidate genes, pathways and mechanisms for alcoholism: an expanded convergent functional genomics approach. Pharmacogenomics J 2007; 7: 222-256.

21. Le-Niculescu H, Balaraman Y, Patel S, Tan J, Sidhu K, Jerome RE et al. Towards understanding the schizophrenia code: an expanded convergent functional genomics approach. Am J Med Genet B Neuropsychiatr Genet 2007; 144: 129-158.

22. Le-Niculescu H, McFarland M, Ogden C, Balaraman Y, Patel S, Tan J et al. Phenomic, convergent functional genomic, and biomarker studies in a stress-reactive genetic animal model of bipolar disorder and co-morbid alcoholism. Am J Med Genet B 2008; 147B: 134-166.

23. Niculescu AB, Le-Niculescu H. The P-value illusion: how to improve (psychiatric) genetic studies. Am J Med Genet B Neuropsychiatr Genet 2010; 153B: 847-849.

24. Schuckit MA, Smith TL, Chacko Y. Evaluation of a depression-related model of alcohol problems in 430 probands from the San Diego prospective study. Drug Alcohol Depend 2006; 82: 194-203.

25. Kuo PH, Gardner CO, Kendler KS, Prescott CA. The temporal relationship of the onsets of alcohol dependence and major depression: using a genetically informative study design. Psychol Med 2006; 36: 1153-1162.

26. Nurnberger Jr Jl, Wiegand R, Bucholz K, O'Connor S, Meyer ET, Reich T et al. A family study of alcohol dependence: coaggregation of multiple disorders in relatives of alcoholdependent probands. Arch Gen Psychiatry 2004; 61: 1246-1256.

27. Lim GP, Calon F, Morihara T, Yang F, Teter B, Ubeda $O$ et al. A diet enriched with the omega-3 fatty acid docosahexaenoic acid reduces amyloid burden in an aged Alzheimer mouse model. J Neurosci 2005; 25: 3032-3040.

28. Niculescu AB, Lulow LL, Ogden CA, Le-Niculescu H, Salomon DR, Schork NJ et al. PhenoChipping of psychotic disorders: a novel approach for deconstructing and quantitating psychiatric phenotypes. Am J Med Genet B Neuropsychiatr Genet 2006; 141: 653-662.

29. Ogden CA, Rich ME, Schork NJ, Paulus MP, Geyer MA, Lohr JB et al. Candidate genes, pathways and mechanisms for bipolar (manic-depressive) and related disorders: an expanded convergent functional genomics approach. Mol Psychiatry 2004; 9: 1007-1029.

30. Le-Niculescu H, Kurian SM, Yehyawi N, Dike C, Patel SD, Edenberg HJ et al. Identifying blood biomarkers for mood disorders using convergent functional genomics. Mol Psychiatry 2009; 14: 156-174.

31. Kurian SM, Le-Niculescu H, Patel SD, Bertram D, Davis J, Dike $C$ et al. Identification of blood biomarkers for psychosis using convergent functional genomics. Mol Psychiatry 2011; 16: 37-58

32. Monteggia LM, Luikart B, Barrot M, Theobold D, Malkovska I, Nef S et al. Brain-derived neurotrophic factor conditional knockouts show gender differences in depression-related behaviors. Biol Psychiatry 2007; 61: 187-197.

33. Niculescu AB, Akiskal HS. Sex hormones, Darwinism, and depression. Arch Gen Psychiatry 2001; 58: 1083-1084; author reply 5-6.

34. Niculescu III AB, Akiskal HS. Proposed endophenotypes of dysthymia: evolutionary, clinical and pharmacogenomic considerations. Mol Psychiatry 2001; 6: 363-366.

35. Patel SD, Le-Niculescu H, Koller DL, Green SD, Lahiri DK, McMahon FJ et al. Coming to grips with complex disorders: genetic risk prediction in bipolar disorder using panels of genes identified through convergent functional genomics. Am J Med Genet B Neuropsychiatr Genet 2010; 153B: 850-877.

36. Vawter MP, Tomita H, Meng F, Bolstad B, Li J, Evans S et al. Mitochondrial-related gene expression changes are sensitive to agonal-pH state: implications for brain disorders. Mol Psychiatry 2006; 11: 615, 663-679.

37. O'Brien WT, Klein PS. Validating GSK3 as an in vivo target of lithium action. Biochem Soc Trans 2009; 37(Pt 5): 1133-1138.

38. Svenningsson P, Tzavara ET, Carruthers R, Rachleff I, Wattler S, Nehls $M$ et al. Diverse psychotomimetics act through a common signaling pathway. Science 2003; 302 : 1412-1415.

39. Perlis RH, Smoller JW, Ferreira MA, McQuillin A, Bass $\mathrm{N}$, Lawrence $\mathrm{J}$ et al. A genomewide association study of response to lithium for prevention of recurrence in bipolar disorder. Am J Psychiatry 2009; 166: 718-725.

40. Benes FM, Lim B, Matzilevich D, Subburaju S, Walsh JP. Circuitry-based gene expression profiles in GABA cells of the trisynaptic pathway in schizophrenics versus bipolars. Proc Natl Acad Sci USA 2008; 105: 20935-20940.
41. Sequeira A, Mamdani F, Ernst C, Vawter MP, Bunney WE, Lebel V et al. Global brain gene expression analysis links glutamatergic and GABAergic alterations to suicide and major depression. PLoS One 2009; 4: e6585.

42. Rao JS, Harry GJ, Rapoport SI, Kim HW. Increased excitotoxicity and neuroinflammatory markers in postmortem frontal cortex from bipolar disorder patients. Mol Psychiatry 2010 15: 384-392.

43. Segman RH, Shefi N, Goltser-Dubner T, Friedman N, Kaminski N, Shalev AY. Peripheral blood mononuclear cell gene expression profiles identify emergent post-traumatic stress disorder among trauma survivors. Mol Psychiatry 2005; 10: 500 513,425

44. Morita K, Saito T, Ohta M, Ohmori T, Kawai K, Teshima-Kondo S et al. Expression analysis of psychological stress-associated genes in peripheral blood leukocytes. Neurosci Lett 2005; 381: 57-62.

45. Horiuchi $Y$, Nakayama J, Ishiguro $H$, Ohtsuki $T$, Detera-Wadleigh SD, Toyota $T$ et al. Possible association between a haplotype of the GABA-A receptor alpha 1 subunit gene (GABRA1) and mood disorders. Biol Psychiatry 2004; 55: 40-45.

46. Breuer $\mathrm{R}$, Hamshere ML, Strohmaier J, Mattheisen M, Degenhardt F, Meier $S$ et al. Independent evidence for the selective influence of $\operatorname{GABA}(\mathrm{A})$ receptors on one component of the bipolar disorder phenotype. Mol Psychiatry; advance online publication, 15 June 2010 [e-pub ahead of print]

47. Donner J, Pirkola S, Silander K, Kananen L, Terwilliger JD, Lonnqvist J et al. An association analysis of murine anxiety genes in humans implicates novel candidate genes for anxiety disorders. Biol Psychiatry 2008; 64: 672-680.

48. Begemann M, Sargin D, Rossner MJ, Bartels C, Theis F, Wichert SP et al. Episode-specific differential gene expression of peripheral blood mononuclear cells in rapid cycling supports novel treatment approaches. Mol Med 2008; 14: 546-552.

49. Lee KW, Lee SH, Kim H, Song JS, Yang SD, Paik SG et al. Progressive cognitive impairment and anxiety induction in the absence of plaque deposition in C57BL/6 inbred mice expressing transgenic amyloid precursor protein. J Neurosci Res 2004; 76: $572-580$.

50. Reyes TM, Walker JR, DeCino C, Hogenesch JB, Sawchenko PE. Categorically distinct acute stressors elicit dissimilar transcriptional profiles in the paraventricular nucleus of the hypothalamus. J Neurosci 2003; 23: 5607-5616.

51. Tkachev D, Mimmack ML, Ryan MM, Wayland M, Freeman T, Jones PB et al. Oligodendrocyte dysfunction in schizophrenia and bipolar disorder. Lancet 2003; 362 798-805.

52. Haroutunian V, Katsel P, Dracheva S, Stewart DG, Davis KL. Variations in oligodendrocyte-related gene expression across multiple cortical regions: implications for the pathophysiology of schizophrenia. Int J Neuropsychopharmacol 2007; 10 : 565-573.

53. McGrath CL, Glatt SJ, Sklar P, Le-Niculescu H, Kuczenski R, Doyle AE et al. Evidence for genetic association of RORB with bipolar disorder. BMC Psychiatry 2009; 9: 70 .

54. Basselin M, Kim HW, Chen M, Ma K, Rapoport SI, Murphy RC et al. Lithium modifies brain arachidonic and docosahexaenoic metabolism in rat lipopolysaccharide model of neuroinflammation. J Lipid Res 2010; 51: 1049-1056.

55. Ostacher MJ, Perlis RH, Nierenberg AA, Calabrese J, Stange JP, Salloum I et al. Impact of substance use disorders on recovery from episodes of depression in bipolar disorder patients: prospective data from the Systematic Treatment Enhancement Program for Bipolar Disorder (STEP-BD). Am J Psychiatry 2010; 167: 289-297.

56. Shaldubina A, Einat $H$, Szechtman $H$, Shimon $H$, Belmaker RH. Preliminary evaluation of oral anticonvulsant treatment in the quinpirole model of bipolar disorder. J Neural Transm 2002; 109: 433-440.

57. Gould TD, Einat H, Bhat R, Manji HK. AR-A014418, a selective GSK-3 inhibitor, produces antidepressant-like effects in the forced swim test. Int J Neuropsychopharmacol 2004; 7 387-390.

58. Einat H, Manji HK, Gould TD, Du J, Chen G. Possible involvement of the ERK signaling cascade in bipolar disorder: behavioral leads from the study of mutant mice. Drug News Perspect 2003; 16: 453-463.

59. Einat H, Manji HK. Cellular plasticity cascades: genes-to-behavior pathways in animal models of bipolar disorder. Biol Psychiatry 2006; 59: 1160-1171.

60. Einat $\mathrm{H}$. Establishment of a battery of simple models for facets of bipolar disorder: a practical approach to achieve increased validity, better screening and possible insights into endophenotypes of disease. Behav Genet 2007; 37: 244-255.

61. Roybal K, Theobold D, Graham A, DiNieri JA, Russo SJ, Krishnan V et al. Mania-like behavior induced by disruption of CLOCK. Proc Natl Acad Sci USA 2007; 104: 6406-6411.

62. Chen G, Henter ID, Manji HK. Translational research in bipolar disorder: emerging insights from genetically based models. Mol Psychiatry 2010; 15: 883-895.

63. Gould TD, O'Donnell KC, Picchini AM, Dow ER, Chen G, Manji HK. Generation and behavioral characterization of beta-catenin forebrain-specific conditional knock-out mice. Behav Brain Res 2008; 189: 117-125.

64. Kubota M, Kasahara T, Iwamoto K, Komori A, Ishiwata M, Miyauchi T et al. Therapeutic implications of down-regulation of cyclophilin D in bipolar disorder. Int $J$ Neuropsychopharmacol 2010; 13: 1355-1368.

65. Kasahara T, Kubota M, Miyauchi T, Noda Y, Mouri A, Nabeshima T et al. Mice with neuron-specific accumulation of mitochondrial DNA mutations show mood disorder-like phenotypes. Mol Psychiatry 2006; 11: 577-593, 523. 
66. Lavebratt C, Sjoholm LK, Partonen T, Schalling M, Forsell Y. PER2 variantion is associated with depression vulnerability. Am J Med Genet B Neuropsychiatr Genet 2010; 153B: $570-581$.

67. Lavebratt C, Sjoholm LK, Soronen P, Paunio T, Vawter MP, Bunney WE et al. CRY2 is associated with depression. PLOS One 2010; 5: e9407.

68. Sjoholm LK, Kovanen L, Saarikoski ST, Schalling M, Lavebratt C, Partonen T. CLOCK is suggested to associate with comorbid alcohol use and depressive disorders. J Circadian Rhythms 2010; 8: 1.

69. Bunney Jr WE, Murphy DL, Goodwin FK, Borge GF. The "switch process" in manicdepressive illness. I. A systematic study of sequential behavioral changes. Arch Gen Psychiatry 1972; 27: 295-302.

70. Koob GF. The neurobiology of addiction: a neuroadaptational view relevant for diagnosis. Addiction 2006; 101(Suppl 1): 23-30.

71. Niculescu III AB. Polypharmacy in oligopopulations: what psychiatric genetics can teach biological psychiatry. Psychiatr Genet 2006; 16: 241-244.

72. Sommer W, Arlinde C, Heilig M. The search for candidate genes of alcoholism: evidence from expression profiling studies. Addict Biol 2005; 10: 71-79.

73. Sugawara $\mathrm{H}$, Iwamoto $\mathrm{K}$, Bundo $M$, Ishiwata $M$, Ueda J, Kakiuchi $C$ et al. Effect of mood stabilizers on gene expression in lymphoblastoid cells. J Neural Transm 2010; 117 155-164

74. Lewis CM, Ng MY, Butler AW, Cohen-Woods S, Uher R, Pirlo K et al. Genome-wide association study of major recurrent depression in the U.K. population. Am J Psychiatry 2010; 167: 949-957.

75. Szczepankiewicz A, Skibinska M, Hauser J, Slopien A, Leszczynska-Rodziewicz A, Kapelski $\mathrm{P}$ et al. Association analysis of the GSK-3beta T-50C gene polymorphism with schizophrenia and bipolar disorder. Neuropsychobiology 2006; 53: 51-56.

76. Lachman HM, Pedrosa E, Petruolo OA, Cockerham M, Papolos A, Novak T et al. Increase in GSK3beta gene copy number variation in bipolar disorder. Am J Med Genet $B$ Neuropsychiatr Genet 2007; 144B: 259-265.

77. Kalscheuer VM, Musante L, Fang C, Hoffmann K, Fuchs C, Carta E et al. A balanced chromosomal translocation disrupting ARHGEF9 is associated with epilepsy, anxiety, aggression, and mental retardation. Hum Mutat 2009; 30: 61-68.

78. Kaabi B, Gelernter J, Woods SW, Goddard A, Page GP, Elston RC. Genome scan for loc predisposing to anxiety disorders using a novel multivariate approach: strong evidence for a chromosome 4 risk locus. Am J Hum Genet 2006; 78: 543-553.

79. Gaiteri C, Guilloux JP, Lewis DA, Sibille E. Altered gene synchrony suggests a combined hormone-mediated dysregulated state in major depression. PLoS One 2010; 5: e9970.

80. Thibault C, Lai C, Wilke N, Duong B, Olive MF, Rahman S et al. Expression profiling of neural cells reveals specific patterns of ethanol-responsive gene expression. Mol Pharmacol 2000; 58: 1593-1600.

81. Cichon S, Schumacher J, Muller DJ, Hurter M, Windemuth C, Strauch K et al. A genome screen for genes predisposing to bipolar affective disorder detects a new susceptibility locus on 8q. Hum Mol Genet 2001; 10: 2933-2944.

82. Del Zompo M, Severino G, Ardau R, Chillotti C, Piccardi M, Dib C et al. Genome-scan for bipolar disorder with sib-pair families in the Sardinian population: a new susceptibility locus on chromosome 1p22-p21? Am J Med Genet B Neuropsychiatr Genet 2010; 153B: 1200-1208.

83. Edenberg HJ, Koller DL, Xuei X, Wetherill L, McClintick JN, Almasy L et al. Genome-wide association study of alcohol dependence implicates a region on chromosome 11. Alcohol Clin Exp Res 2010; 34: 840-852.

84. Bell RL, Kimpel MW, McClintick JN, Strother WN, Carr LG, Liang T et al. Gene expression changes in the nucleus accumbens of alcohol-preferring rats following chronic ethano consumption. Pharmacol Biochem Behav 2009; 94: 131-147.

85. Sokolov BP, Jiang L, Trivedi NS, Aston C. Transcription profiling reveals mitochondrial, ubiquitin and signaling systems abnormalities in postmortem brains from subjects with a history of alcohol abuse or dependence. J Neurosci Res 2003; 72: 756-767.

86. Etain B, Mathieu F, Rietschel M, Maier W, Albus M, McKeon P et al. Genome-wide scan for genes involved in bipolar affective disorder in 70 European families ascertained through a bipolar type I early-onset proband: supportive evidence for linkage at 3p14. Mol Psychiatry 2006; 11: 685-694.

87. Segman RH, Goltser-Dubner T, Weiner I, Canetti L, Galili-Weisstub E, Milwidsky A et al. Blood mononuclear cell gene expression signature of postpartum depression. Mol Psychiatry 2010; 15: 93-100, 2.

88. Sklar P, Pato MT, Kirby A, Petryshen TL, Medeiros H, Carvalho $\mathrm{C}$ et al. Genome-wide scan in Portuguese Island families identifies $5 q 31-5 q 35$ as a susceptibility locus fo schizophrenia and psychosis. Mol Psychiatry 2004; 9: 213-218.

89. Hong KS, Mclnnes LA, Service SK, Song T, Lucas J, Silva S et al. Genetic mapping using haplotype and model-free linkage analysis supports previous evidence for a locus predisposing to severe bipolar disorder at 5q31-33. Am J Med Genet B Neuropsychiatr Genet 2004; 125B: 83-86.

90. Crowe RR, Goedken R, Samuelson S, Wilson R, Nelson J, Noyes Jr R. Genomewide survey of panic disorder. Am J Med Genet 2001; 105: 105-109.

91. Mukherjee S, Coque L, Cao JL, Kumar J, Chakravarty S, Asaithamby A et al. Knockdown of clock in the ventral tegmental area through RNA interference results in a mixed state of mania and depression-like behavior. Biol Psychiatry 2010; 68: 503-511.

92. Torrey EF, Barci BM, Webster MJ, Bartko JJ, Meador-Woodruff JH, Knable MB. Neurochemical markers for schizophrenia, bipolar disorder, and major depression in postmortem brains. Biol Psychiatry 2005; 57: 252-260.
93. Noble EP, Blum K, Ritchie T, Montgomery A, Sheridan PJ. Allelic association of the D2 dopamine receptor gene with receptor-binding characteristics in alcoholism. Arch Gen Psychiatry 1991; 48: 648-654.

94. Kraschewski A, Reese J, Anghelescu I, Winterer G, Schmidt LG, Gallinat J et al. Association of the dopamine D2 receptor gene with alcohol dependence: haplotypes and subgroups of alcoholics as key factors for understanding receptor function. Pharmacogenet Genomics 2009; 19: 513-527.

95. Munafo MR, Matheson IJ, Flint J. Association of the DRD2 gene Taq1A polymorphism and alcoholism: a meta-analysis of case-control studies and evidence of publication bias. Mol Psychiatry 2007; 12: 454-461.

96. Smith L, Watson M, Gates S, Ball D, Foxcroft D. Meta-analysis of the association of the Taq1A polymorphism with the risk of alcohol dependency: a HuGE gene-disease association review. Am J Epidemiol 2008; 167: 125-138.

97. Ponce G, Perez-Gonzalez R, Aragues M, Palomo T, Rodriguez-Jimenez R, JimenezArriero MA et al. The ANKK1 kinase gene and psychiatric disorders. Neurotox Res 2009; 16: $50-59$.

98. Yang BZ, Kranzler HR, Zhao H, Gruen JR, Luo X, Gelernter J. Haplotypic variants in DRD2, ANKK1, TTC12, and NCAM1 are associated with comorbid alcohol and drug dependence. Alcohol Clin Exp Res 2008; 32: 2117-2127.

99. Sipila T, Kananen L, Greco D, Donner J, Silander K, Terwilliger JD et al. An association analysis of circadian genes in anxiety disorders. Biol Psychiatry 2010; 67: 1163-1170.

100. Massat I, Souery D, Del-Favero J, Van Gestel S, Serretti A, Macciardi F et al. Positive association of dopamine D2 receptor polymorphism with bipolar affective disorder in a European Multicenter Association Study of affective disorders. Am J Med Genet 2002; 114: $177-185$.

101. Maron E, Nikopensius T, Koks S, Altmae S, Heinaste E, Vabrit K et al. Association study of 90 candidate gene polymorphisms in panic disorder. Psychiatr Genet 2005; 15: 17-24.

102. Surget A, Wang Y, Leman S, Ibarguen-Vargas $Y$, Edgar N, Griebel G et al. Corticolimbic transcriptome changes are state-dependent and region-specific in a rodent model of depression and of antidepressant reversal. Neuropsychopharmacology 2009; 34: 1363-1380.

103. Iwamoto K, Bundo M, Yamamoto M, Ozawa H, Saito T, Kato T. Decreased expression of NEFH and PCP4/PEP19 in the prefrontal cortex of alcoholics. Neurosci Res 2004; 49: 379-385.

104. Miller GE, Chen E, Sze J, Marin T, Arevalo JM, Doll R et al. A functional genomic fingerprint of chronic stress in humans: blunted glucocorticoid and increased NF-kappaB signaling. Biol Psychiatry 2008; 64: 266-272.

105. Doyle AE, Biederman J, Ferreira MA, Wong P, Smoller JW, Faraone SV. Suggestive linkage of the child behavior checklist juvenile bipolar disorder phenotype to 1p21, 6p21, and 8q21. J Am Acad Child Adolesc Psychiatry 2010; 49: 378-387.

106. Nash MW, Huezo-Diaz P, Williamson RJ, Sterne A, Purcell S, Hoda F et al. Genome-wide linkage analysis of a composite index of neuroticism and mood-related scales in extreme selected sibships. Hum Mol Genet 2004; 13: 2173-2182.

107. Ishikawa M, Mizukami K, Iwakiri M, Asada T. Immunohistochemical and immunoblot analysis of Dopamine and cyclic AMP-regulated phosphoprotein, relative molecular mass 32,000 (DARPP-32) in the prefrontal cortex of subjects with schizophrenia and bipolar disorder. Prog Neuropsychopharmacol Biol Psychiatry 2007; 31: 1177-1181.

108. Torres KC, Souza BR, Miranda DM, Nicolato R, Neves FS, Barros AG et al. The leukocytes expressing DARPP-32 are reduced in patients with schizophrenia and bipolar disorder. Prog Neuropsychopharmacol Biol Psychiatry 2009; 33: 214-219.

109. Tabakoff B, Saba L, Printz M, Flodman P, Hodgkinson C, Goldman D et al. Genetical genomic determinants of alcohol consumption in rats and humans. BMC Biol 2009; 7: 70.

110. Benes FM, Matzilevich D, Burke RE, Walsh J. The expression of proapoptosis genes is increased in bipolar disorder, but not in schizophrenia. Mol Psychiatry 2006; 11: 241-251.

111. Kawai T, Morita K, Masuda K, Nishida K, Shikishima M, Ohta M et al. Gene expression signature in peripheral blood cells from medical students exposed to chronic psychological stress. Biol Psychol 2007; 76: 147-155.

112. Fallin MD, Lasseter VK, Avramopoulos D, Nicodemus KK, Wolyniec PS, McGrath JA et al. Bipolar I disorder and schizophrenia: a 440-single-nucleotide polymorphism screen of 64 candidate genes among Ashkenazi Jewish case-parent trios. Am J Hum Genet 2005; 77 : 918-936.

113. McQuillin A, Rizig M, Gurling HM. A microarray gene expression study of the molecular pharmacology of lithium carbonate on mouse brain mRNA to understand the neurobiology of mood stabilization and treatment of bipolar affective disorder. Pharmacogenet Genomics 2007; 17: 605-617.

114. Lewohl JM, Wang L, Miles MF, Zhang L, Dodd PR, Harris RA. Gene expression in human alcoholism: microarray analysis of frontal cortex. Alcohol Clin Exp Res 2000; 24: 1873-1882.

115. Cordeiro Q, Talkowski ME, Chowdari KV, Wood J, Nimgaonkar V, Vallada H. Association and linkage analysis of RGS4 polymorphisms with schizophrenia and bipolar disorder in Brazil. Genes Brain Behav 2005; 4: 45-50.

116. Bertsch B, Ogden CA, Sidhu K, Le-Niculescu H, Kuczenski R, Niculescu AB. Convergent functional genomics: a Bayesian candidate gene identification approach for complex disorders. Methods 2005; 37: 274-279.

117. Aston C, Jiang L, Sokolov BP. Transcriptional profiling reveals evidence for signaling and oligodendroglial abnormalities in the temporal cortex from patients with major depressive disorder. Mol Psychiatry 2005; 10: 309-322. 
118. Middleton FA, Pato CN, Gentile KL, McGann L, Brown AM, Trauzzi M et al. Gene expression analysis of peripheral blood leukocytes from discordant sib-pairs with schizophrenia and bipolar disorder reveals points of convergence between genetic and functional genomic approaches. Am J Med Genet B Neuropsychiatr Genet 2005; 136: 12-25.

119. Zubenko GS, Maher B, Hughes III HB, Zubenko WN, Stiffler JS, Kaplan BB et al. Genome-wide linkage survey for genetic loci that influence the development of depressive disorders in families with recurrent, early-onset, major depression. Am J Med Genet $B$ Neuropsychiatr Genet 2003; 123: 1-18.

120. Cassidy F, Zhao C, Badger J, Claffey E, Dobrin S, Roche S et al. Genome-wide scan of bipolar disorder and investigation of population stratification effects on linkage: support for susceptibility loci at 4q21, 7q36, 9p21, 12q24, 14q24, and 16p13. Am J Med Genet B Neuropsychiatr Genet 2007; 144B: 791-801.

121. Goes FS, Zandi PP, Miao K, McMahon FJ, Steele J, Willour VL et al. Mood-incongruent psychotic features in bipolar disorder: familial aggregation and suggestive linkage to 2p11-q14 and 13q21-33. Am J Psychiatry 2007; 164: 236-247.

122. Rogers PJ, Hohoff C, Heatherley SV, Mullings EL, Maxfield PJ, Evershed RP et al. Association of the anxiogenic and alerting effects of caffeine with ADORA2A and ADORA1 polymorphisms and habitual level of caffeine consumption. Neuropsychopharmacology 2010; 35: 1973-1983.

123. Maron E, Kallassalu K, Tammiste A, Kolde R, Vilo J, Toru I et al. Peripheral gene expression profiling of CCK-4-induced panic in healthy subjects. Am J Med Genet $B$ Neuropsychiatr Genet 2010; 153B: 269-274.

124. Deckert J, Nothen MM, Franke P, Delmo C, Fritze J, Knapp M et al. Systematic mutation screening and association study of the $\mathrm{A} 1$ and $\mathrm{A} 2 \mathrm{a}$ adenosine receptor genes in panic disorder suggest a contribution of the A2a gene to the development of disease. Mol Psychiatry 1998; 3: 81-85.

125. Hamilton SP, Slager SL, De Leon AB, Heiman GA, Klein DF, Hodge SE et al. Evidence for genetic linkage between a polymorphism in the adenosine $2 A$ receptor and panic disorder. Neuropsychopharmacology 2004; 29: 558-565.

126. Barley K, Dracheva S, Byne W. Subcortical oligodendrocyte- and astrocyte-associated gene expression in subjects with schizophrenia, major depression and bipolar disorder. Schizophr Res 2009; 112: 54-64.

127. Detera-Wadleigh SD, Badner JA, Berrettini WH, Yoshikawa T, Goldin LR, Turner G et al. A high-density genome scan detects evidence for a bipolar-disorder susceptibility locus on 13q32 and other potential loci on 1q32 and 18p11.2. Proc Natl Acad Sci USA 1999; 96 : 5604-5609.

128. Liang KY, Wang Y, Shugart YY, Grados M, Fyer AJ, Rauch S et al. Evidence for potential relationship between SLC1A1 and a putative genetic linkage region on chromosome 14q to obsessive-compulsive disorder with compulsive hoarding. Am J Med Genet B Neuropsychiatr Genet 2008; 147B: 1000-1002.

129. Gelernter J, Page GP, Bonvicini K, Woods SW, Pauls DL, Kruger S. A chromosome 14 risk locus for simple phobia: results from a genomewide linkage scan. Mol Psychiatry 2003; 8: 71-82.

130. Pennington K, Beasley CL, Dicker P, Fagan A, English J, Pariante $\mathrm{CM}$ et al. Prominent synaptic and metabolic abnormalities revealed by proteomic analysis of the dorsolateral prefrontal cortex in schizophrenia and bipolar disorder. Mol Psychiatry 2008; 13: 1102-1117.

131. Seelan RS, Khalyfa A, Lakshmanan J, Casanova MF, Parthasarathy RN. Deciphering the lithium transcriptome: microarray profiling of lithium-modulated gene expression in human neuronal cells. Neuroscience 2008; 151: 1184-1197.

132. Fullerton JM, Donald JA, Mitchell PB, Schofield PR. Two-dimensional genome scan identifies multiple genetic interactions in bipolar affective disorder. Biol Psychiatry 2010; 67: $478-486$.

133. Lambert D, Middle F, Hamshere ML, Segurado R, Raybould R, Corvin A et al. Stage 2 of the Wellcome Trust UK-Irish bipolar affective disorder sibling-pair genome screen: evidence for linkage on chromosomes 6q16-q21, 4q12-q21, 9p21, 10p14-p12 and 18q22. Mol Psychiatry 2005; 10: 831-841.

134. Foroud $T$, Bice $P$, Castelluccio $P, B o$, Miller $L$, Ritchotte $A$ et al. Identification of quantitative trait loci influencing alcohol consumption in the high alcohol drinking and low alcohol drinking rat lines. Behav Genet 2000; 30: 131-140.

135. Conti B, Maier R, Barr AM, Morale MC, Lu X, Sanna PP et al. Region-specific transcriptional changes following the three antidepressant treatments electro convulsive therapy, sleep deprivation and fluoxetine. Mol Psychiatry 2007; 12: 167-189.

136. Liu J, Lewohl JM, Harris RA, lyer VR, Dodd PR, Randall PK et al. Patterns of gene expression in the frontal cortex discriminate alcoholic from nonalcoholic individuals. Neuropsychopharmacology 2006; 31: 1574-1582.

137. Bergen AW, Yang XR, Bai Y, Beerman MB, Goldstein AM, Goldin LR. Genomic regions linked to alcohol consumption in the Framingham Heart Study. BMC Genet 2003; 4 (Suppl 1): S101.

138. Thorgeirsson TE, Oskarsson H, Desnica N, Kostic JP, Stefansson JG, Kolbeinsson H et al. Anxiety with panic disorder linked to chromosome $9 q$ in Iceland. Am J Hum Genet 2003; 72: 1221-1230.

139. Wang SS, Kamphuis W, Huitinga I, Zhou JN, Swaab DF. Gene expression analysis in the human hypothalamus in depression by laser microdissection and real-time PCR: the presence of multiple receptor imbalances. Mol Psychiatry 2008; 13: 786-799, 741.
140. Treutlein J, Cichon S, Ridinger M, Wodarz N, Soyka M, Zill P et al. Genome-wide association study of alcohol dependence. Arch Gen Psychiatry 2009; 66: 773-784.

141. Mill J, Kiss E, Baji I, Kapornai K, Daroczy G, Vetro A et al. Association study of the estrogen receptor alpha gene (ESR1) and childhood-onset mood disorders. Am J Med Genet B Neuropsychiatr Genet 2008; 147B: 1323-1326.

142. Wang H, Zhu YZ, Wong PT, Farook JM, Teo AL, Lee LK et al. cDNA microarray analysis of gene expression in anxious PVG and SD rats after cat-freezing test. Exp Brain Res 2003; 149: 413-421.

143. Klempan TA, Rujescu D, Merette C, Himmelman C, Sequeira A, Canetti L et al. Profiling brain expression of the spermidine/spermine N1-acetyltransferase 1 (SAT1) gene in suicide. Am J Med Genet B Neuropsychiatr Genet 2009; 150B: 934-943.

144. Maziade M, Roy MA, Chagnon YC, Cliche D, Fournier JP, Montgrain N et al. Shared and specific susceptibility loci for schizophrenia and bipolar disorder: a dense genome scan in Eastern Quebec families. Mol Psychiatry 2005; 10: 486-499.

145. Erhardt A, Czibere L, Roeske D, Lucae S, Unschuld PG, Ripke S et al. TMEM132D, a new candidate for anxiety phenotypes: evidence from human and mouse studies. Mol Psychiatry; advance online publication, 6 April 2010 [e-pub ahead of print].

146. Bilkei-Gorzo A, Racz I, Michel K, Zimmer A, Klingmuller D, Zimmer A. Behavioral phenotype of pre-proenkephalin-deficient mice on diverse congenic backgrounds. Psychopharmacology (Berl) 2004; 176: 343-352.

147. Palo OM, Soronen P, Silander K, Varilo T, Tuononen K, Kieseppa T et al. Identification of susceptibility loci at $7 \mathrm{q} 31$ and $9 \mathrm{p} 13$ for bipolar disorder in an isolated population. Am J Med Genet B Neuropsychiatr Genet 2010; 153B: 723-735.

148. Kim KS, Han PL. Optimization of chronic stress paradigms using anxiety- and depressionlike behavioral parameters. J Neurosci Res 2006; 83: 497-507.

149. Sherva R, Rice JP, Neuman RJ, Rochberg N, Saccone NL, Bierut LJ. Associations and interactions between SNPs in the alcohol metabolizing genes and alcoholism phenotypes in European Americans. Alcohol Clin Exp Res 2009; 33: 848-857.

150. Sequeira A, Klempan T, Canetti L, ffrench-Mullen J, Benkelfat C, Rouleau GA et al. Patterns of gene expression in the limbic system of suicides with and without major depression. Mol Psychiatry 2007; 12: 640-655.

151. Shyn SI, Shi J, Kraft JB, Potash JB, Knowles JA, Weissman MM et al. Novel loci for major depression identified by genome-wide association study of Sequenced Treatment Alternatives to Relieve Depression and meta-analysis of three studies. Mol Psychiatry 2011; 16: 202-215.

152. Sherrin T, Blank T, Saravana R, Rayner M, Spiess J, Todorovic C. Region specific gene expression profile in mouse brain after chronic corticotropin releasing factor receptor 1 activation: the novel role for diazepam binding inhibitor in contextual fear conditioning. Neuroscience 2009; 162: 14-22.

153. Fallin MD, Lasseter VK, Wolyniec PS, McGrath JA, Nestadt G, Valle D et al. Genomewide linkage scan for bipolar-disorder susceptibility loci among Ashkenazi Jewish families. Am J Hum Genet 2004; 75: 204-219.

154. McBride WJ, Kimpel MW, Schultz JA, McClintick JN, Edenberg HJ, Bell RL. Changes in gene expression in regions of the extended amygdala of alcohol-preferring rats after binge-like alcohol drinking. Alcohol 2010; 44: 171-183.

155. Park N, Juo SH, Cheng R, Liu J, Loth JE, Lilliston B et al. Linkage analysis of psychosis in bipolar pedigrees suggests novel putative loci for bipolar disorder and shared susceptibility with schizophrenia. Mol Psychiatry 2004; 9: 1091-1099.

156. Schulze TG, Buervenich S, Badner JA, Steele CJ, Detera-Wadleigh SD, Dick D et al. Loci on chromosomes $6 q$ and $6 p$ interact to increase susceptibility to bipolar affective disorder in the national institute of mental health genetics initiative pedigrees. Biol Psychiatry 2004; 56: 18-23.

157. Sun F, Cheng R, Flanders WD, Yang Q, Khoury MJ. Whole genome association studies for genes affecting alcohol dependence. Genet Epidemiol 1999; 17(Suppl 1): S337-S342.

158. Liebl C, Panhuysen M, Putz B, Trumbach D, Wurst W, Deussing JM et al. Gene expression profiling following maternal deprivation: involvement of the brain Renin-Angiotensin system. Front Mol Neurosci 2009; 2 : 1.

159. Beasley CL, Pennington K, Behan A, Wait R, Dunn MJ, Cotter D. Proteomic analysis of the anterior cingulate cortex in the major psychiatric disorders: evidence for diseaseassociated changes. Proteomics 2006; 6: 3414-3425.

160. Bernard R, Kerman IA, Thompson RC, Jones EG, Bunney WE, Barchas JD et al. Altered expression of glutamate signaling, growth factor, and glia genes in the locus coeruleus of patients with major depression. Mol Psychiatry; advance online publication, 13 April 2010 [e-pub ahead of print].

161. Dick DM, Nurnberger Jr J, Edenberg HJ, Goate A, Crowe R, Rice J et al. Suggestive linkage on chromosome 1 for a quantitative alcohol-related phenotype. Alcohol Clin Exp Res 2002; 26: 1453-1460.

162. Mozhui K, Karlsson RM, Kash TL, Inne J, Norcross M, Patel S et al. Strain differences in stress responsivity are associated with divergent amygdala gene expression and glutamate-mediated neuronal excitability. J Neurosci 2010; 30: 5357-5367.

163. Orsetti M, Di Brisco F, Rinaldi M, Dallorto D, Ghi P. Some molecular effectors of antidepressant action of quetiapine revealed by DNA microarray in the frontal cortex of anhedonic rats. Pharmacogenet Genomics 2009; 19: 600-612.

164. Ising M, Lucae S, Binder EB, Bettecken T, Uhr M, Ripke S et al. A genomewide association study points to multiple loci that predict antidepressant drug treatment outcome in depression. Arch Gen Psychiatry 2009; 66: 966-975. 
165. Brandish PE, Su M, Holder DJ, Hodor P, Szumiloski J, Kleinhanz RR et al. Regulation of gene expression by lithium and depletion of inositol in slices of adult rat cortex. Neuron 2005; 45: 861-872.

166. Hill SY, Shen S, Zezza N, Hoffman EK, Perlin M, Allan W. A genome wide search for alcoholism susceptibility genes. Am J Med Genet B Neuropsychiatr Genet 2004; 128 102-113.

167. Pato CN, Pato MT, Kirby A, Petryshen TL, Medeiros H, Carvalho C et al. Genome-wide scan in Portuguese Island families implicates multiple loci in bipolar disorder: fine mapping adds support on chromosomes 6 and 11. Am J Med Genet B Neuropsychiatr Genet2004 127B: $30-34$.

168. Choudary PV, Molnar M, Evans SJ, Tomita H, Li JZ, Vawter MP et al. Altered cortical glutamatergic and GABAergic signal transmission with glial involvement in depression. Proc Natl Acad Sci USA 2005; 102: 15653-15658

169. Mitsuyama H, Little KY, Sieghart W, Devaud LL, Morrow AL. GABA(A) receptor alpha1, alpha4, and beta3 subunit mRNA and protein expression in the frontal cortex of human alcoholics. Alcohol Clin Exp Res 1998; 22: 815-822.

170. Song J, Koller DL, Foroud T, Carr K, Zhao J, Rice J et al. Association of GABA(A) receptors and alcohol dependence and the effects of genetic imprinting. Am J Med Genet B Neuropsychiatr Genet 2003; 117: 39-45.

171. Craddock N, Jones L, Jones IR, Kirov G, Green EK, Grozeva D et al. Strong genetic evidence for a selective influence of $\mathrm{GABA}(\mathrm{A})$ receptors on a component of the bipola disorder phenotype. Mol Psychiatry 2010; 15: 146-153.

172. Lind PA, Macgregor S, Vink JM, Pergadia ML, Hansell NK, de Moor MH et al. A genomewide association study of nicotine and alcohol dependence in Australian and Dutch populations. Twin Res Hum Genet 2010; 13: 10-29.

173. O'Dushlaine C, Kenny E, Heron E, Donohoe G, Gill M, Morris D et al. Molecular pathways involved in neuronal cell adhesion and membrane scaffolding contribute to schizophrenia and bipolar disorder susceptibility. Mol Psychiatry 2011; 16: 286-292.

174. Smoller JW, Acierno Jr JS, Rosenbaum JF, Biederman J, Pollack MH, Meminger S et al. Targeted genome screen of panic disorder and anxiety disorder proneness using homology to murine QTL regions. Am J Med Genet 2001; 105: 195-206.

175. Meira-Lima IV, Pereira AC, Mota GF, Krieger JE, Vallada H. Angiotensinogen and angiotensin converting enzyme gene polymorphisms and the risk of bipolar affective disorder in humans. Neurosci Lett 2000; 293: 103-106.

176. Su YA, Wu J, Zhang L, Zhang Q, Su DM, He P et al. Dysregulated mitochondrial genes and networks with drug targets in postmortem brain of patients with posttraumatic stress disorder (PTSD) revealed by human mitochondria-focused cDNA microarrays. Int J Biol Sci 2008; 4: 223-235.

177. Xuei X, Flury-Wetherill L, Almasy L, Bierut L, Tischfield J, Schuckit M et al. Association analysis of genes encoding the nociceptin receptor (OPRL1) and its endogenous ligand (PNOC) with alcohol or illicit drug dependence. Addict Biol 2008; 13: 80-87.

178. Kohen R, Kirov S, Navaja GP, Happe HK, Hamblin MW, Snoddy JR et al. Gene expression profiling in the hippocampus of learned helpless and nonhelpless rats. Pharmacogenomics J 2005; 5: 278-291.

179. Worst TJ, Tan JC, Robertson DJ, Freeman WM, Hyytia P, Kiianmaa K et al. Transcriptome analysis of frontal cortex in alcohol-preferring and nonpreferring rats. J Neurosci Res 2005; 80: 529-538.

180. Flatscher-Bader T, van der Brug M, Hwang JW, Gochee PA, Matsumoto I, Niwa S et al. Alcohol-responsive genes in the frontal cortex and nucleus accumbens of human alcoholics. J Neurochem 2005; 93: 359-370.

181. Ryan MM, Lockstone HE, Huffaker SJ, Wayland MT, Webster MJ, Bahn S. Gene expression analysis of bipolar disorder reveals downregulation of the ubiquitin cycle and alterations in synaptic genes. Mol Psychiatry 2006; 11: 965-978.

182. Morissette J, Villeneuve A, Bordeleau L, Rochette D, Laberge C, Gagne B et al. Genomewide search for linkage of bipolar affective disorders in a very large pedigree derived from a homogeneous population in quebec points to a locus of major effect on chromosome 12q23-q24. Am J Med Genet 1999; 88: 567-587.

183. Weissman MM, Fyer AJ, Haghighi F, Heiman G, Deng Z, Hen R et al. Potential panic disorder syndrome: clinical and genetic linkage evidence. Am J Med Genet 2000; 96: 24-35.

184. Soria V, Martinez-Amoros E, Escaramis G, Valero J, Perez-Egea R, Garcia C et al. Differential association of circadian genes with mood disorders: CRY1 and NPAS2 are associated with unipolar major depression and CLOCK and VIP with bipolar disorder Neuropsychopharmacology 2010; 35: 1279-1289.

185. Maron E, Hettema JM, Shlik J. Advances in molecular genetics of panic disorder Mol Psychiatry 2010; 15: 681-701.

186. Luciano M, Houlihan LM, Harris SE, Gow AJ, Hayward C, Starr JM et al. Association of existing and new candidate genes for anxiety, depression and personality traits in older people. Behav Genet 2010; 40: 518-532.

187. Hamilton SP, Fyer AJ, Durner M, Heiman GA, Baisre de Leon A, Hodge SE et al. Further genetic evidence for a panic disorder syndrome mapping to chromosome 13q. Proc Nat Acad Sci USA 2003; 100: 2550-2555.

188. Fyer AJ, Hamilton SP, Durner M, Haghighi F, Heiman GA, Costa R et al. A third-pass genome scan in panic disorder: evidence for multiple susceptibility loci. Biol Psychiatry 2006; 60: 388-401.

189. Ishikawa M, Mizukami K, Iwakiri M, Hidaka S, Asada T. Immunohistochemical and immunoblot study of GABA(A) alpha1 and beta2/3 subunits in the prefrontal cortex of subjects with schizophrenia and bipolar disorder. Neurosci Res 2004; 50: 77-84.
190. Johnson C, Drgon T, McMahon FJ, Uhl GR. Convergent genome wide association results for bipolar disorder and substance dependence. Am J Med Genet B Neuropsychiatr Genet 2009; 150B: 182-190.

191. Xing G, Zhang L, Russell S, Post R. Reduction of dopamine-related transcription factors Nurr1 and NGFI-B in the prefrontal cortex in schizophrenia and bipolar disorders. Schizophr Res 2006; 84: 36-56.

192. Etheridge N, Lewohl JM, Mayfield RD, Harris RA, Dodd PR. Synaptic proteome changes in the superior frontal gyrus and occipital cortex of the alcoholic brain. Proteomics Clin Appl 2009; 3: 730-742

193. Dick DM, Aliev F, Bierut L, Goate A, Rice J, Hinrichs A et al. Linkage analyses of IQ in the collaborative study on the genetics of alcoholism (COGA) sample. Behav Genet 2006; 36 : $77-86$

194. Benes FM, Todtenkopf MS, Logiotatos P, Williams M. Glutamate decarboxylase(65)immunoreactive terminals in cingulate and prefrontal cortices of schizophrenic and bipolar brain. J Chem Neuroanat 2000; 20: 259-269.

195. Heckers S, Stone D, Walsh J, Shick J, Koul P, Benes FM. Differential hippocampal expression of glutamic acid decarboxylase 65 and 67 messenger RNA in bipolar disorder and schizophrenia. Arch Gen Psychiatry 2002; 59: 521-529.

196. Lappalainen J, Krupitsky E, Kranzler HR, Luo X, Remizov M, Pchelina S et al. Mutation screen of the GAD2 gene and association study of alcoholism in three populations. Am J Med Genet B Neuropsychiatr Genet 2007; 144B: 183-192.

197. Unschuld PG, Ising M, Specht M, Erhardt A, Ripke S, Heck A et al. Polymorphisms in the GAD2 gene-region are associated with susceptibility for unipolar depression and with a risk factor for anxiety disorders. Am J Med Genet B Neuropsychiatr Genet 2009; 150B: 1100-1109.

198. Martin MV, Rollins B, Sequeira PA, Mesen A, Byerley W, Stein R et al. Exon expression in lymphoblastoid cell lines from subjects with schizophrenia before and after glucose deprivation. BMC Med Genomics 2009; 2: 62.

199. Schuckit MA, Edenberg HJ, Kalmijn J, Flury L, Smith TL, Reich T et al. A genome-wide search for genes that relate to a low level of response to alcohol. Alcohol Clin Exp Res 2001; 25: 323-329.

200. Karssen AM, Her S, Li JZ, Patel PD, Meng F, Bunney Jr WE et al. Stress-induced changes in primate prefrontal profiles of gene expression. Mol Psychiatry 2007; 12: 10891102.

201. Derijk RH, van Leeuwen N, Klok MD, Zitman FG. Corticosteroid receptor-gene variants: modulators of the stress-response and implications for mental health. Eur $\mathrm{J}$ Pharmacol 2008; 585: 492-501

202. Weaver IC, Meaney MJ, Szyf M. Maternal care effects on the hippocampal transcriptome and anxiety-mediated behaviors in the offspring that are reversible in adulthood. Proc Natl Acad Sci USA 2006; 103: 3480-3485

203. Jurata LW, Bukhman YV, Charles V, Capriglione F, Bullard J, Lemire AL et al. Comparison of microarray-based mRNA profiling technologies for identification of psychiatric disease and drug signatures. J Neurosci Methods 2004; 138: 173-188.

204. Youngs RM, Chu MS, Meloni EG, Naydenov A, Carlezon Jr WA, Konradi C. Lithium administration to preadolescent rats causes long-lasting increases in anxiety-like behavior and has molecular consequences. J Neurosci 2006; 26: 6031-6039.

205. McNamara RK, Ostrander M, Abplanalp W, Richtand NM, Benoit SC, Clegg DJ. Modulation of phosphoinositide-protein kinase $\mathrm{C}$ signal transduction by omega-3 fatty acids: implications for the pathophysiology and treatment of recurrent neuropsychiatric illness. Prostaglandins Leukot Essent Fatty Acids 2006; 75: 237-257.

206. Pandey GN, Dwivedi Y, Ren X, Rizavi HS, Roberts RC, Conley RR et al. Altered expression and phosphorylation of myristoylated alanine-rich $C$ kinase substrate (MARCKS) in postmortem brain of suicide victims with or without depression. $J$ Psychiatr Res 2003; 37: 421-432.

207. Hattori E, Toyota T, Ishitsuka Y, Iwayama Y, Yamada K, Ujike $\mathrm{H}$ et al. Preliminary genome-wide association study of bipolar disorder in the Japanese population. Am J Med Genet B Neuropsychiatr Genet 2009; 150B: 1110-1117.

208. Chu TT, Liu Y, Kemether E. Thalamic transcriptome screening in three psychiatric states. J Hum Genet 2009; 54: 665-675.

209. Maron E, Hettema JM, Shlik J. Advances in molecular genetics of panic disorder. $\mathrm{Mol}$ Psychiatry 2010; 15: 681-701

210. Stopkova P, Saito T, Fann CS, Papolos DF, Vevera J, Paclt I et al. Polymorphism screening of PIP5K2A: a candidate gene for chromosome 10p-linked psychiatric disorders. Am J Med Genet B Neuropsychiatr Genet 2003; 123B: 50-58.

211. Wray NR, James MR, Mah SP, Nelson M, Andrews G, Sullivan PF et al. Anxiety and comorbid measures associated with PLXNA2. Arch Gen Psychiatry 2007; 64: 318-326.

212. Curtis D, Kalsi G, Brynjolfsson J, Mclnnis M, O'Neill J, Smyth C et al. Genome scan of pedigrees multiply affected with bipolar disorder provides further support for the presence of a susceptibility locus on chromosome 12q23-q24, and suggests the presence of additional loci on 1p and 1q. Psychiatr Genet 2003; 13: 77-84.

213. Gelernter J, Bonvicini K, Page G, Woods SW, Goddard AW, Kruger S et al. Linkage genome scan for loci predisposing to panic disorder or agoraphobia. Am J Med Genet 2001; 105: 548-557.

214. Foroud T, Bucholz KK, Edenberg HJ, Goate A, Neuman RJ, Porjesz B et al. Linkage of an alcoholism-related severity phenotype to chromosome 16. Alcohol Clin Exp Res 1998; 22 . 2035-2042. 
215. Macgregor S, Visscher PM, Knott SA, Thomson P, Porteous DJ, Millar JK et al. A genome scan and follow-up study identify a bipolar disorder susceptibility locus on chromosome 1q42. Mol Psychiatry 2004; 9: 1083-1090.

216. Nakatani N, Ohnishi T, Iwamoto K, Watanabe A, Iwayama $\mathrm{Y}$, Yamashita $\mathrm{S}$ et al. Expression analysis of actin-related genes as an underlying mechanism for mood disorders. Biochem Biophys Res Commun 2007; 352: 780-786.

217. Del Zompo M, Severino G, Ardau R, Chillotti C, Piccardi M, Dib C et al. Genome-scan for bipolar disorder with sib-pair families in the Sardinian population: a new susceptibility locus on chromosome 1p22-p21? Am J Med Genet B Neuropsychiatr Genet 2010; 153B: 1200-1208.

218. Nurnberger Jr Jl, Foroud T, Flury L, Su J, Meyer ET, Hu K et al. Evidence for a locus on chromosome 1 that influences vulnerability to alcoholism and affective disorder. Am J Psychiatry 2001; 158: 718-724.

219. Zandi PP, Badner JA, Steele J, Willour VL, Miao K, MacKinnon DF et al. Genome-wide linkage scan of 98 bipolar pedigrees and analysis of clinical covariates. Mol Psychiatry 2007; 12: 630-639.
220. Bailer U, Leisch F, Meszaros K, Lenzinger E, Willinger U, Strobl R et al. Genome scan for susceptibility loci for schizophrenia and bipolar disorder. Biol Psychiatry 2002; 52 40-52.

221. Sousa JC, Grandela C, Fernandez-Ruiz J, de Miguel R, de Sousa L, Magalhaes Al et al. Transthyretin is involved in depression-like behaviour and exploratory activity J Neurochem 2004; 88: 1052-1058.

Translational Psychiatry is an open-access journal published by Nature Publishing Group. This work is licensed under the Creative Commons Attribution-Noncommercial-No Derivative Works 3.0 Unported License. To view a copy of this license, visit http://creativecommons.org/licenses/by-nc-nd/3.0/

Supplementary Information accompanies the paper on the Translational Psychiatry website (http://www.nature.com/tp) 